\title{
Democracia, instituições de controle e justiça sob a ótica do pluralismo estatal ${ }^{1}$
}

\author{
Rogério B. Arantes ${ }^{2}$ (D) \\ Thiago M. Q. Moreira ${ }^{3}$ (ic
}

\begin{abstract}
O Brasil tem experimentado extraordinária expansão de órgãos de controle e de promoção do acesso à justiça. A atuação desses órgãos suscita, contudo, dúvidas sobre os efeitos provocados no funcionamento da democracia. Este artigo analisa, comparativamente, o desenvolvimento de três instituições do campo da justiça Ministério Público, Polícia Federal e Defensoria Pública - sob a abordagem teórica do pluralismo estatal, enfatizando que agentes públicos atuam em função de interesses próprios de afirmação institucional, lançando-se na esfera pública e em arenas políticas em busca de prerrogativas, funções e autonomia. O resultado, não sem frequentes embates entre esses atores, é a pluralização no interior do Estado, com a proliferação de órgãos que espelham suas próprias ambições. Essa abordagem contribui para compreender o atual cenário, marcado pela controversa interferência de instituições de controle na dinâmica política e democrática.

Palavras-chave: pluralismo estatal; ativismo político; instituições de controle; instituições de justiça; democracia
\end{abstract}

\section{Introdução}

O Brasil tem sido palco de intensa experimentação institucional no que diz respeito a novas formas de acesso à justiça e aos controles democráticos da administração pública (Arantes et al., 2010; Arantes e Reis, 2010). Seja na dimensão vertical, seja na dimensão horizontal da accountability, observamos nas últimas décadas uma extraordinária expansão e institucionalização de órgãos e mecanismos de fiscalização do poder público em geral e da classe política em particular. Embora inovações no âmbito do controle interno da administração tenham sido significativas, é no plano externo que se situa o maior número e a maior força das iniciativas de controle. Estas prosperaram especialmente no âmbito do sistema de justiça, envolvendo velhas e novas instituições voltadas à fiscalização dos serviços públicos, à ampliação do acesso à justiça e à investigação e persecução de desvios por parte de agentes públicos. Referimo-nos principalmente aos casos do Ministério Público (MP), da Polícia Federal (PF) e da Defensoria Pública (DP). O protagonismo desses

\footnotetext{
1 Agradecemos aos comentários e sugestões de Cláudio G. Couto, Adrian Gurza Lavalle, Vanessa E. de Oliveira, Débora R. de Almeida, Jeferson Mariano da Silva, Cassio Oliveira e Thiago N. Fonseca.

2 Universidade de São Paulo, Ciência Política. São Paulo (SP), Brasil. E-mail: <rarantes@usp.br>.

3 Universidade de São Paulo, Ciência Política. São Paulo (SP), Brasil. E-mail: <thiago.moreira@usp.br>.
} 
órgãos na esfera social e política tem sido intenso e sistemático, mas a deterioração do sistema político acarretada pelas ações de combate à corrupção e à improbidade administrativa, somada a novas e heterodoxas formas de aplicação do direito penal nessa área, bem como a frequente judicialização de temas e decisões envolvendo políticas públicas, têm levantado dúvidas sobre os reais efeitos desse processo para a democracia brasileira.

O presente artigo pretende organizar os principais marcos da (re)construção institucional do MP, PF e DP, comparando-os a partir de uma perspectiva teórica denominada de pluralismo estatal (Arantes, 2015). Segundo essa abordagem, esses atores estatais agem em função de interesses próprios, de afirmação institucional, e se lançam à conquista de funções e prerrogativas no espaço legal e político da democracia. De "idades" diferentes, uns se espelham nos passos que outros já trilharam, mas nesse processo não é incomum que entrem em conflito entre si, buscando defender e/ou alargar suas fronteiras recíprocas. Nesse sentido, a assim chamada "web of accountability institutions" (Mainwaring e Welna, 2003), defendida por muitos como condição de aperfeiçoamento da própria democracia, não formaria propriamente uma rede, concebida com base num plano prévio e sistemático capaz de Ihe dar coerência. Pelo contrário, a experiência brasileira sugere que a proliferação de instituições de controle e de promoção do acesso à justiça diz respeito mais às ambições de grupos e carreiras estruturadas dentro do próprio Estado, que fazem do discurso da defesa de direitos e da fiscalização do poder público e da classe política uma bandeira de seu próprio desenvolvimento institucional. O resultado geral dessa dinâmica peculiar tem sido antes a pluralização de órgãos no interior do próprio Estado do que a consolidação de um sistema de accountability coerente, que o adensamento da representação política ou a equalização de direitos.

A análise comparada das trajetórias do MP, da PF e da DP nos permitirá demonstrar a existência de um padrão de afirmação institucional que busca associar os interesses materiais das diferentes carreiras às prerrogativas e metas da organização. Cada uma a seu modo, essas três instituições souberam aproveitar as possibilidades abertas pelos movimentos de ampliação do acesso à justiça e de combate à corrupção política. De fato, mais do que o discurso da democratização, foram os discursos do acesso à justiça e do controle do poder político que se mostraram mais promissores e abriram mais oportunidades de inovação institucional nessas últimas décadas ou desde a promulgação da Constituição de 1988. Tem sido a partir do campo da justiça que membros do MP, DP e PF têm lutado pela conquista de espaços privilegiados de atuação e por pontos específicos de fixação na estrutura constitucional do Estado. Nesse processo, ao lado da "linguagem dos direitos", que presidiu a transição democrática e a elaboração do novo texto constitucional, esses atores estatais encontraram nas linguagens da "accountability" (ou, nativamente falando, da fiscalização do poder público e combate à corrupção política), de um lado, e do "acesso à justiça", de outro, os valores normativos capazes de sustentar sua busca por afirmação institucional. 
Estudos recentes sobre o tema da judicialização da política têm proposto que o outro lado da moeda - a politização da justiça - deve ser igualmente problematizado (Avritzer e Marona, 2017; Oliveira e Couto, 2016; Zaffalon L. Cardoso, 2017). Há algum tempo, entretanto, dispomos de estudos específicos sobre as instituições de justiça, que destacam aspectos internos e externos de seu desenvolvimento institucional ${ }^{4}$. Aqueles que focalizaram a motivação endógena das transformações pelas quais passaram essas instituições já apontavam para a judicialização da política como efeito, em grande medida, das ações estratégicas desses atores, motivadas pelo objetivo de autoafirmação institucional. O objetivo do presente artigo, que nos parece inédito, é o de retomar tais estudos e comparar as trajetórias envolvendo três casos - Ministério Público, Defensoria Pública e Polícia Federal - por meio de um esquema analítico capaz de identificar os mecanismos específicos dos processos de afirmação institucional, mas também seus limites e contradições.

A judicialização da política - termo que apresenta em si uma conotação negativa tem sido cada vez mais criticada diante da deterioração do sistema político e da quebra da normalidade democrática do país. A crise é profunda e, em resposta ao bordão "as instituições estão funcionando", muitos questionam a lisura e a legitimidade desse processo, aventando a hipótese de partidarização da própria justiça, destacando sua atuação seletiva e seus métodos abusivos de persecução criminal. Avritzer reconhece, por exemplo, que as ações conduzidas por instituições de controle nos últimos anos aprimoraram a capacidade estatal de combater a corrupção, mas ressalta que "os abusos recentes em relação a direitos dos investigados (...) colocam em questão o avanço generalizado do combate à corrupção no país" e representam um dos principais "impasses da democracia no Brasil" (Avritzer, 2016, p. 112). Avançando na crítica, Avritzer e Marona (2017) afirmam que estaríamos sob uma espécie "pretorianismo jurídico", que tem levado à criminalização da política e colocado em risco a própria democracia. Para outros, entretanto, como Alston et al. (2016), mesmo a crise atual pode ser interpretada como uma janela de oportunidade para consolidar crenças e instituições que têm impulsionado uma democracia inclusiva, fiscalmente responsável, nos marcos de um presidencialismo forte porém cercado de um "lively, competitive, and investigative web of accountability institutions including a very independent and respected judiciary, an honest and competent bureaucracy (by Latin American standards), audit institutions, and an independent media" (Alston et al., 2016, p. 219).

Embora não tenhamos clareza dos efeitos de longo prazo desse processo para a democracia brasileira, o que pretendemos enfatizar é que a dinâmica atual dos controles externos sobre a administração pública e a classe política reflete muito mais uma "política para si" desses órgãos e instituições do que uma "política para outrem", isto é, muito mais do que uma atuação seletiva porque supostamente partidária. Concordamos em parte com

\footnotetext{
4 Do ponto de vista que interessa à presente discussão, ver especialmente Almeida, 2010; Arantes, 2002, 2011a, 2011b; Bonelli, 2002; Kerche, 2009; Madeira, 2014; Moreira, 2016, 2017; Arantes e Moreira, 2015; Sadek, 1995, 1997; Vianna et al., 1997.
} 
o diagnóstico de Oliveira e Couto que consideram a politização da justiça como "o aumento do uso pelos agentes do sistema de justiça, nas decisões por eles suscitadas ou proferidas, de critérios politicamente controversos" (2016, p. 3), mas o objetivo deste artigo é demonstrar que tais decisões não estão vinculadas a objetivos políticos externos, e sim a uma ideia de autoafirmação institucional no médio e longo prazos. Na próxima seção, "Pluralização no interior do Estado e ativismo político estatal", oferecemos elementos para uma abordagem teórica do problema, oriundos principalmente do institucionalismo histórico, com o qual a perspectiva do pluralismo estatal pode dialogar e se desenvolver. Na sequência, em "Afirmação institucional no sistema de justiça: fatores explicativos e primeiras aplicações", apresentamos os conceitos que informam o modelo de análise utilizado para comparar as trajetórias das três instituições analisadas. Concluímos o artigo em "Considerações finais: uma releitura do sistema de justiça e accountability brasileiro", tratando de algumas consequências desse padrão de desenvolvimento institucional na configuração dos controles democráticos no Brasil, bem como tarefas de pesquisas futuras.

\section{Pluralização no interior do Estado e ativismo político estatal}

O controle exercido por órgãos do mundo do direito sobre a política, as políticas públicas e os políticos é notável no Brasil, e vem avançando em três esferas distintas e complementares (Arantes et al., 2010): 1) o controle judicial da constitucionalidade das leis, que tem por objetivo preservar as regras que presidem o funcionamento da polity democrática ${ }^{5}$; 2 ) o controle que incide sobre forma e conteúdo das políticas elaboradas e implementadas pelos governantes (policy); e 3) o controle dos ocupantes de cargos públicos, no que diz respeito à sua conduta pública e administrativa, com impactos notáveis sobre a politics. Somados, esses três tipos de controle representam um grande cerco à atividade política, nas dimensões constitucional, governamental e administrativa. Se, de um lado, podem elevar o nível geral de responsabilização e accountability do sistema político, por outro têm suscitado críticas cada vez mais frequentes quanto ao excesso de interferência que ocasionam.

Embora a construção desse complexo arranjo não tenha obedecido a um plano prévio e deliberado, as histórias de transformação do MP, DP e PF revelam um padrão de afirmação institucional comum, baseado num comportamento estratégico das categorias profissionais que integram essas instituições, configurando um fenômeno de consequências teóricas ainda não sistematizadas pela ciência política. Trata-se do ativismo político de atores estatais empenhados em conquistar e manter poder vis-à-vis outras instituições, muitas vezes rivais, no interior do Estado. Conforme pretendemos

\footnotetext{
5 Pode-se estabelecer uma distinção entre três dimensões da política: polity, policy e politics. A primeira diz respeito à estrutura do sistema político (o seu marco constitucional), a segunda, a seus produtos ordinários (as políticas públicas) e a terceira concerne à atividade política (ao jogo político propriamente dito). Para uma discussão mais pormenorizada a esse respeito, ver Couto e Arantes (2006).
} 
demonstrar, a evolução dessas instituições e as disputas nas quais estão inseridas decorrem dos interesses e ações de carreiras de servidores públicos, ou seja, de grupos constituídos e articulados dentro do próprio Estado.

Trabalhos anteriores ressaltaram a atuação política de atores estatais na evolução do Ministério Público (Arantes, 2002), da Defensoria Pública (Moreira, 2016, 2017; Arantes e Moreira, 2015) e da Polícia Federal (Arantes, 2011a, 2011b, 2015), e outros estudos observaram a ocorrência de comportamento semelhante no Tribunal de Contas da União (Fonseca, 2014) e na Controladoria Geral da União (Olivieri, 2010). Esses trabalhos compartilham um traço comum: revelam atores inseridos na máquina estatal atuando politicamente quando buscam estender os limites da policy pela qual são responsáveis, empurram as fronteiras de suas funções institucionais e, por meio de atividades típicas de grupos de interesse, tentam obter, junto às instâncias políticas decisórias, a aprovação de medidas legais capazes de fortalecer as instituições que integram e/ou remodelar os parâmetros das políticas públicas que desempenham.

$\mathrm{O}$ ativismo de atores oriundos do Estado é um fenômeno que desafia abordagens tradicionais da ciência política, uma vez que a maior parte da literatura que avalia a ação de atores coletivos sobre o processo político-decisório concentra-se na análise de atores societais (grupos de interesse, movimentos sociais, associações, sindicatos, lobbies etc.). Estudos desse tipo se inserem nas "society-centered theories", conforme definiu Skocpol (1985), e incluem o pluralismo (Truman, 1951; Dahl, 1991), o neocorporativismo (Schmitter, 1992; Offe, 1989), teorias dos movimentos sociais (Alonso, 2009) e teorias da sociedade civil (Gurza Lavalle, 1999). Cada uma dessas abordagens teóricas busca explicar o comportamento e a interferência de determinados atores societais na política e nas atividades governamentais, ignorando ou restringindo a importância de outros tantos atores. No entanto, a atuação política de grupos estruturados no interior do Estado, formados por carreiras públicas com objetivos próprios, não foi captada por essas perspectivas centradas em atores societais.

A abordagem teórica que mais se aproxima do que almejamos neste artigo é o institucionalismo histórico (Thelen e Steinmo, 1992; Pierson e Skocpol, 2002; Hall e Taylor, 2003), corrente que oferece melhores perspectivas para identificar a atuação política de carreiras públicas. Não se trata de fazer aqui uma resenha exaustiva dessa literatura, mas de destacar que seu ponto de partida é o reconhecimento do Estado enquanto ator, ou seja, a noção de que certas organizações, mesmo que inseridas no ambiente estatal e fazendo disso uma vantagem, podem perseguir objetivos políticos que não são simplesmente reflexo de preferências e demandas de grupos da sociedade (Skocpol, 1985; Marques, 1997). É a ideia de "autonomia estatal", frequentemente retratada em investigações empíricas sobre o "insulamento burocrático" (Geddes, 1990; Sikkink, 1993; Nunes, 2010), que avaliam condições sob as quais parte do funcionalismo público encontra-se suficientemente isolada de interesses de grupos sociais para implantar uma agenda política supostamente neutra e técnica, mas que muitas vezes espelha os interesses da própria carreira de servidores. Contemporânea ao surgimento dessa 
abordagem, outra referência importante para análise do Estado é o trabalho de Michael Mann, que defendeu, em contraposição às literaturas funcionalistas e marxistas sobre o Estado, a autonomia do poder das elites estatais em relação às ingerências de grupos sociais, destacando que a arena estatal não se resume a um mero instrumento do conflito de classes, pois constitui espaço organizacional com poder infraestrutural próprio, que Ihe confere capacidade para penetrar na sociedade civil e implementar decisões políticas (Mann, 1984, p. 201).

De maneira semelhante, a abordagem aqui proposta guarda proximidade com a literatura sobre burocracia e políticas públicas, particularmente a que investiga a "burocracia do nível de rua" (Lipsky, 1980; Lotta, 2010) - cujo foco incide na fase de implementação das políticas, quando os burocratas estão em contato direto com o públicoalvo da ação estatal - pois essa perspectiva também tende a realçar aspectos como autonomia, capacidade de interferir no funcionamento das políticas e o problema democrático daí decorrente.

Apesar dos avanços do institucionalismo histórico no sentido de enxergar o Estado como ator, conceitos como insulamento burocrático e autonomia estatal não alcançam o fenômeno discutido neste artigo. Mesmo a contribuição de Mann, que busca defender a independência do Estado, não capta a atuação política de grupos formados no interior da máquina pública, tal como o fenômeno aqui analisado. Na verdade, tais conceitos apontam para a discricionariedade e para a capacidade dos atores estatais de influenciarem a definição de políticas públicas durante o exercício de suas atividades profissionais específicas, isto é, quando os membros da burocracia estão desempenhando as funções que são próprias aos cargos que ocupam. Embora não se limitem a essa dimensão da ação política baseada no insulamento burocrático, as instituições que examinamos no presente artigo também se utilizam de razoável grau de autonomia para definir os rumos da policy sob sua responsabilidade, em regra motivadas por fatores endógenos ligados à sua própria afirmação institucional.

Com efeito, o fenômeno encontrado nos processos de (re)construção institucional do MP, DP e PF não pode ser reduzido ao frame teórico das abordagens mencionadas. Em tais casos, é possível observar que atores constituídos dentro do Estado agem politicamente na esfera social e em instâncias de decisão política, com o propósito de aprovar medidas legais e constitucionais, mas também administrativas, destinadas a fortalecer a instituição que compõem. Desempenham, portanto, a função de advocacy de projetos que visam alterar a estrutura institucional e as competências funcionais de suas próprias repartições públicas, sempre com o propósito de fortalecer garantias, prerrogativas e privilégios. Para aprovar tais projetos, os atores estatais em questão se organizam em entidades coletivas, fazem alianças com movimentos sociais e lideranças políticas, realizam lobby para pressionar instâncias decisórias e defendem por meio de campanhas públicas na mídia seus objetivos, muitas vezes enfrentando a oposição de outros grupos que possuem interesses e projetos que correm na mesma faixa. Em síntese, 
esses atores estatais fazem política, muitas vezes invocando um repertório de ações típico de grupos de interesse e de movimentos sociais.

Em contraste com os fenômenos descritos pelas literaturas relacionadas à autonomia estatal e à burocracia, podemos classificar o comportamento dos atores estatais analisados no presente artigo como ativismo político estatal, ou ativismo político de atores estatais, tal como introduzido por Moreira (2016) na análise sobre o desenvolvimento institucional da Defensoria Pública. Esse tipo de ativismo não se confunde com outros dois frequentemente invocados por estudos contíguos ao nosso: o chamado ativismo judicial, que busca apontar as ações de juízes e membros do Ministério Público que ultrapassam os limites de suas funções tradicionais, e o ativismo institucional de lideranças e movimentos sociais que ascendem a cargos no governo e a partir daí buscam avançar suas agendas e projetos (Abers e Tatagiba, 2015). Nosso conceito de ativismo político estatal se distingue do primeiro por não estar adstrito à interferência no resultado da policy (embora por vezes os atores aqui analisados também mergulhem em ativismo judicial) e se distingue do segundo por ser praticado por atores estatais e não sociais (embora possam guardar com esses últimos eventuais vínculos e alianças estratégicas). Motivados e mobilizados endogenamente, esses atores estatais agem politicamente, no plano da politics, para promover seus próprios projetos institucionais e produzir, quando não ratificar, seu encaixe no sistema institucional da polity.

Em outra frente de estudos, a respeito de espaços participativos e movimentos sociais no Brasil, tem-se destacado a existência de novas relações entre sociedade e Estado no campo da participação, identificando novas rotas de interdependência entre atores estatais e societais (Gurza Lavalle e Szwako, 2015) e novas estratégias de inserção no aparato estatal com vistas a influenciar diretamente as políticas públicas (Abers e Von Büllow, 2011; Abers, Serafim e Tatagiba, 2015; Silva e Oliveira, 2011), as quais desafiam as noções mais tradicionais de representação política (Gurza Lavalle, Houtzager e Castello, 2006; Almeida, 2014). No entanto, apesar de capturarem formas de ativismo no interior do Estado, tais estudos não alcançaram as experiências que vão no sentido contrário, isto é, as que partem do interior do Estado para o campo aberto da sociedade e da política. Assim, uma coisa é observar como atores constituídos ou oriundos da sociedade assumem funções no aparato estatal, como faz Dowbor (2012) em sua pesquisa sobre o movimento sanitarista; outra é examinar, na contramão desse fluxo, os processos de evolução institucional do Ministério Público, da Defensoria e da Polícia Federal como exemplos de atores formados no interior do Estado, controlados por determinadas carreiras públicas, mais especificamente jurídicas, e que se comportam como ativistas em defesa de seus próprios projetos de afirmação institucional, direcionando-se para a sociedade em busca de apoio e pressionando os demais atores políticos com vistas a esse fim. Publicamente, o processo de consolidação e expansão institucional dos órgãos analisados aqui pauta-se na "linguagem dos direitos", que orientou a transição democrática no Brasil e a elaboração do texto constitucional de 1988, a partir da qual tais atores estatais reivindicam funções públicas e garantias legais para a promoção da accountability e para a ampliação do acesso 
à justiça. Assim, a fiscalização do poder público e a abertura dos canais de defesa de direitos constituem valores normativos que sustentam a busca por afirmação institucional desses atores. Conforme apresentamos adiante, mais do que o discurso da democratização, temas relacionados ao acesso à justiça e ao controle do poder político revelaram-se mais promissores e têm aberto mais oportunidades para inovação institucional ao longo das três décadas que se seguiram à promulgação da Constituição. É a partir do discurso de expansão e fortalecimento da justiça que membros do MP, da DP e da PF têm lutado para conquistar espaços privilegiados de fixação na estrutura constitucional do Estado. Se o discurso ou a "linguagem dos direitos" podem ser considerados fatores-chave na explicação do fenômeno, cabe igualmente destacar que eles contemplam certas variações decorrentes do contexto e das especificidades de cada instituição. No limite, como tais instituições também competem entre si por espaços e funções, os discursos podem entrar em choque e rivalidades e ameaças são frequentes em suas relações recíprocas.

Consideramos que o conceito de pluralismo estatal (Arantes, 2015) pode contribuir para a compreensão do comportamento de atores estatais no desenvolvimento das instituições do sistema de justiça examinadas neste artigo, em linha com trabalhos recentes que adotaram essa perspectiva (Arantes, 2015; Moreira, 2016). Ao expor a ambição de membros do MP e da PF em busca de afirmação institucional, Arantes (2015) demonstrou que uma consequência dessa atuação política de setores da máquina pública é a pluralização do Estado, diante do surgimento e desenvolvimento de novos órgãos públicos "liderados por elites burocráticos o de carreras públicas especiales, volcados no hacia la representación de grupos sociales, sino a la realización de metas constitucionales e institucionales específicas" (Arantes, 2015, p. 30). Como tais instituições não obedecem a um plano prévio e global de desenvolvimento institucional, construído externamente, nem estão ancoradas no Demos ou guardam com esses vínculos de representação e de accountability, forma-se, assim, uma espécie de pluralismo no interior do Estado, da mesma forma como a teoria democrática nos ensinou a enxergar o pluralismo políticosocial constituído por atores provenientes da sociedade e marcante em regimes democráticos. O conceito retrata, portanto, o desenvolvimento institucional decorrente da luta de atores estatais por afirmação institucional, que resulta na pluralização da estrutura intraestatal.

Não obstante, a noção de pluralismo estatal é adequada para capturar não apenas a consequência da atuação dos atores estatais, mas também a multiplicação do ativismo político entre diversos setores e órgãos da máquina pública (Moreira, 2016). Isso porque o paralelo com a teoria pluralista permite enxergar as associações e carreiras de servidores públicos como atores no jogo político, ou seja, como grupos de interesses agindo em nome de seus próprios projetos e ambições. Essa perspectiva também se aproxima dos trabalhos de Bonelli (2002), Bonelli e Oliveira (2003) e Almeida (2016), que, partindo os primeiros da sociologia das profissões e o terceiro da perspectiva de Bourdieu, analisam as carreiras 
jurídicas no interior do Estado e sua busca por autonomia profissional. O fato de se estruturarem em carreira e de pertencerem ao mundo jurídico confere diversas vantagens no que diz respeito à superação de problemas típicos da ação coletiva. Desde a socialização nos mesmos bancos escolares, passando pela força das associações corporativas ao espaço mais autônomo e estruturado em torno de prerrogativas e privilégios típicos da justiça, as carreiras jurídicas parecem encontrar mais facilmente do que outras os caminhos capazes de levar a uma ação coletiva bem-sucedida.

Por meio do conceito de pluralismo estatal, contudo, busca-se revelar e examinar a existência de uma multiplicidade de atores estatais e conflitos entre eles, em torno da apropriação de garantias, mas também da definição de políticas públicas sob sua direta responsabilidade, visando consolidar seu encaixe específico no sistema institucional mais amplo. Observam-se, com isso, os choques entre diferentes carreiras públicas decorrentes das disputas por mais espaço, funções, prerrogativas, benefícios materiais (salários, auxílios etc.) e autonomia na estrutura constitucional do Estado. Sendo assim, o conceito de pluralismo estatal pode ser empregado de maneira ampla, para compreender tanto a pluralização no interior do Estado, com a fixação de múltiplas instituições de controle, quanto a disseminação do ativismo político entre atores estatais que impulsiona esse processo.

\section{Afirmação institucional no sistema de justiça: fatores explicativos e primeiras aplicações}

A abordagem teórica proposta neste artigo nos permite observar os fatores determinantes da trajetória de (re)construção das instituições judiciais analisadas, pois destaca o caráter endógeno da atuação dos atores do sistema de justiça, expondo seus objetivos e as barreiras que precisam enfrentar. No plano das instituições judiciais, os objetivos consistem em atingir autonomia financeira e administrativa, prerrogativas funcionais e remunerações significativamente elevadas para o padrão do serviço público brasileiro. O êxito dessa busca por afirmação institucional, geralmente associada a pretensões corporativas e profissionais, depende fundamentalmente de três fatores: 1) o "encaixe" específico que cada instituição logra promover e consolidar junto ao sistema institucional mais amplo; 2) o grau de coesão existente entre seus próprios membros, o que ajuda a entender também as diferenças de trajetórias entre MP, DP e PF (pois apresentam diferentes graus dessa coesão interna); 3) a capacidade de vencer conflitos "de fronteira" (ou de, pelo menos, resistir a eles), que ameaçam modificar seu rol de competências ou sua autonomia.

Nossa definição de encaixe institucional é inspirada na ideia seminal de Skocpol (1992, p. 54) e praticada pelo institucionalismo histórico para se referir ao ponto de junção que atores sociais mobilizados logram encontrar ou mesmo construir junto ao Estado. $\mathrm{Na}$ formulação mais recente de Gurza Lavalle et al., "são sedimentações institucionais de processos de interação socioestatal que ganham vida própria (artefatos: instrumentos, 
regras, leis, programas, instâncias, órgãos) e mediante as quais atores sociais são, em alguma medida, bem-sucedidos em dirigir de modo contínuo a seletividade das instituições políticas ao seu favor, ampliando sua capacidade de agir" (2017, p. 19-20). Todavia, nossa formulação de encaixe institucional é dirigida ao ponto de junção que atores estatais logram construir no interior do sistema no qual estão inseridos. Em geral, tais pontos dizem respeito a fendas ou lacunas associadas a certas funções públicas que são cuidadosamente exploradas e decididamente preenchidas por esses atores. Uma vez que se obtenha êxito nesse sentido, o encaixe passa a funcionar como mecanismo ou alavanca de sua capacidade de agir externamente, fortalece sua posição vis-à-vis outros órgãos do sistema institucional e reconfigura a estrutura do próprio Estado, pluralizando-o nos termos que advogamos aqui.

O Quadro 1 apresenta os principais elementos que caracterizam as trajetórias das três instituições examinadas neste artigo, organizados a partir de nossas categorias centrais. Analisamos adiante comparativamente os três casos a partir desse quadro de referências. 


\section{Quadro 1}

Trajetórias de afirmação institucional de MP, DP e PF

\begin{tabular}{|c|c|c|c|}
\hline & Ministério Público & Defensoria Pública & Polícia Federal \\
\hline Encaixe & $\begin{array}{l}\text { Substituição processual/ } \\
\text { Representação extraordinária da } \\
\text { sociedade civil hipossuficiente }\end{array}$ & $\begin{array}{l}\text { Defesa dos necessitados } \\
\text { (individuais) }\end{array}$ & Qualidade da prova \\
\hline $\begin{array}{l}\text { Coesão } \\
\text { interna }\end{array}$ & Elevada & Média & Baixa \\
\hline $\begin{array}{l}\text { Conflitos de } \\
\text { fronteiras }\end{array}$ & $\begin{array}{l}\text { Poder de investigação, em disputa } \\
\text { com a Polícia } \\
\text { Condução da delação premiada, em } \\
\text { disputa com a Polícia } \\
\text { Uso da Ação Civil Pública, em } \\
\text { disputa com a Defensoria } \\
\text { Acordos de leniência, em disputa } \\
\text { com AGU, CGU e TCU }\end{array}$ & $\begin{array}{l}\text { Autonomia institucional, em conflito } \\
\text { com o Ministério Público } \\
\text { Uso da Ação Civil Pública, em disputa } \\
\text { com o Ministério Publico } \\
\text { Controle dos recursos financeiros } \\
\text { destinados à assistência jurídica, em } \\
\text { conflito com OAB } \\
\text { Controle da política de assistência } \\
\text { jurídica, em conflito com advogados } \\
\text { privados e PGE }\end{array}$ & $\begin{array}{l}\text { Poder de investigação, em } \\
\text { disputa com o Ministério } \\
\text { Público } \\
\text { Condução da delação } \\
\text { premiada, em disputa com o } \\
\text { Ministério Público } \\
\text { Carreiras policiais internas em } \\
\text { conflito por prerrogativas e } \\
\text { postos de comando }\end{array}$ \\
\hline \multicolumn{4}{|c|}{ Outros aspectos relevantes } \\
\hline Marcos legais & $\begin{array}{l}\text { Código do Processo Civil (1973) } \\
\text { Lei Orgânica Nacional do MP (LC } \\
\text { 40, 1981) } \\
\text { Lei Ambiental (Lei 6938, 1981) } \\
\text { Lei da Ação Civil Pública (1985) } \\
\text { Constituição (1988) } \\
\text { Pós-88: Leis definindo direitos } \\
\text { difusos e coletivos }\end{array}$ & $\begin{array}{l}\text { Constituição (1988) } \\
\text { EC } 41 / 2003 \\
\text { EC } 45 / 2004 \\
\text { EC } 69 / 2012 \\
\text { EC } 74 / 2013 \\
\text { EC } 80 / 2014 \\
\text { Lei } 11448 \text { (2007) } \\
\text { Lei Orgânica Nacional da Defensoria } \\
\text { (LC } 80 / 1994 \text { e LC } 132 / 2009 \text { ) }\end{array}$ & $\begin{array}{l}\text { Constituição (1988) } \\
\text { MP } 657 / 2014 \\
\text { Lei das Organizações } \\
\text { Criminosas (Lei 12850, 2013) } \\
\text { PEC 412/2009 }\end{array}$ \\
\hline $\begin{array}{l}\text { Linguagem/ } \\
\text { Ideologia }\end{array}$ & $\begin{array}{l}\text { Ideologia do "voluntarismo } \\
\text { político" } \\
\text { Hipossuficiência da sociedade civil }\end{array}$ & $\begin{array}{l}\text { Acesso à justiça aos necessitados; } \\
\text { Defesa dos direitos humanos; } \\
\text { Proteção de grupos em situação de } \\
\text { vulnerabilidade }\end{array}$ & $\begin{array}{l}\text { Combate à corrupção e ao } \\
\text { crime organizado; } \\
\text { "Polícia de Estado" }\end{array}$ \\
\hline
\end{tabular}

Fonte: Elaborado pelos autores.

As histórias de afirmação institucional do MP, da PF e da DP passam pela construção de encaixes que, embora presentes em suas definições constitucionais e obrigações legais, necessitam ser especificados pela análise. Concretamente, o encaixe que potencializou o desenvolvimento do Ministério Público foi a condição alcançada de substituto processual ou representante extraordinário da sociedade na defesa de interesses e direitos coletivos. No caso da Defensoria Pública, foi ter alcançado a condição de prestador da assistência jurídica e judicial à população juridicamente necessitada, completando assim um ciclo de ampliação do acesso à justiça. No caso da Polícia Federal, foi ter se proposto a recuperar a qualidade da prova nas investigações criminais. Tais encaixes derivam da percepção dos atores que integram essas instituições de que funções públicas a elas relacionadas (ou que podem ser atribuídas a elas) constituem janelas de oportunidade para promover a afirmação institucional dos órgãos aos quais pertencem. Embora tais órgãos sejam 
públicos, a cada passo na autonomia que conquistam, mais pertencentes às respectivas carreiras jurídicas e menos sujeitos a mecanismos externos de controle se tornam. Ao longo do tempo, a percepção dos atores pode mudar, seu discurso público pode se atualizar e novas funções podem ser agregadas àquelas que Ihes deram projeção inicial, passando a ser empregadas para potencializar suas atividades e prerrogativas e para ampliar seu espaço no encaixe institucional em que estão inseridos. Dessa forma, é notável como nos últimos anos o MP passou a enfatizar sua importância também na persecução penal de combate à corrupção, ao passo que a Defensoria tem buscado ampliar sua atuação para abranger toda a população genericamente classificada como vulnerável, não se restringindo a atender apenas os economicamente necessitados, e a PF se vê alçada a outras missões que não apenas a de combate à corrupção que pavimentou sua ascensão.

É difícil, nos limites de um artigo, reconstruir no detalhe as trajetórias que resultaram nesses encaixes iniciais ${ }^{6}$, mas, para as experiências do MP e da DP, uma boa forma de fazê-lo é considerar as ondas de transformações processuais e do direito para promover a ampliação do acesso à justiça descritas por Cappelletti e Garth (1988). Enquanto a primeira onda envolveu, em diversos países, a concessão de assistência jurídica aos mais pobres, por meio principalmente de advogados pagos pelo Estado para a defesa de causas individuais, a segunda onda se baseou na crítica ao individualismo do ordenamento jurídico liberal e na necessidade de dar representação jurídica e meios efetivos de acesso ao Judiciário aos interesses e direitos transindividuais ou coletivos.

No Brasil, essa segunda onda teve lugar no final dos anos 1970 e início da década de 1980, quando o meio jurídico se mobilizou pela ampliação do acesso à justiça para causas coletivas. A estratégia dos juristas estava centrada em três aspectos principais ${ }^{7}: 1$ ) abertura do ordenamento jurídico a direitos transindividuais ou coletivos; 2) criação de um tipo novo de ação que propiciasse a representação de tais interesses e direitos na esfera judicial; e 3) atribuição dessa capacidade a associações da sociedade civil, num contexto de crítica ao Estado autoritário e de emergência de novos movimentos sociais. Em artigo publicado originalmente em 1975 (Cappelleti, 1977), que exercera forte influência sobre os processualistas brasileiros ("Formazioni sociali e interessi di gruppo davanti allá giustizia"), Cappelletti alertava para a inconveniência de entregar a missão de defesa dos interesses coletivos ao Ministério Público, apontando graves defeitos na instituição ${ }^{8}$. As

\footnotetext{
${ }^{6}$ Essa reconstrução mais detalhada encontra-se nos trabalhos de Arantes (2002, 2011a, 2011b) e Moreira $(2016,2017)$.

7 Os principais juristas que se ocuparam do tema nessa época e iniciaram ampla mobilização foram José Carlos Barbosa Moreira, Waldemar Mariz de Oliveira Jr., Ada Pelegrini Grinover e Kazuo Watanabe. Alguns de seus trabalhos pioneiros e mais influentes foram: Moreira (1977), Oliveira Jr. (1978) e Grinover (1979), apud Arantes (2002).

8 Primeiramente, diz Cappelletti, o promotor, como típico burocrata do Estado, seria incapaz de apresentar o dinamismo que a defesa judicial desses novos direitos exigiria; em segundo lugar, na hipótese bastante frequente de interesses lesados pelo poder público, a vinculação do MP com o Poder Executivo o impediria de realizar uma defesa autônoma desses direitos; por fim, mas não menos importante, faltaria ao MP formação especializada, conhecimento técnico e estrutura adequada, requisitos para uma boa atuação frente a problemas sociais e econômicos de grande complexidade (Cappelletti, 1977, p. 139).
} 
opiniões então se dividiram no meio jurídico e dois projetos de lei foram apresentados ao Congresso Nacional em 1984, um liderado pelos juristas e outro por integrantes do Ministério Público paulista. O projeto do MP, encampado pelo então ministro da Justiça do governo militar, teve tramitação mais célere e foi aprovado em meados de 1985, convertendo-se na Lei 7347/85 da Ação Civil Pública e resultando no fortalecimento da instituição, em detrimento das associações civis 9 .

É fato que o MP vinha numa trajetória ascendente em pleno regime militar, desde que o Código do Processo Civil de 1973 passou a permitir sua atuação em defesa do interesse público não limitado aos interesses da administração pública, que alcançara uma Lei Orgânica Nacional em 1981 - plena de garantias - e, no mesmo ano, a Lei do Meio Ambiente lhe conferira, com exclusividade, a defesa judicial dos direitos difusos na área ambiental. Todavia, sua crescente atuação na esfera cível sempre esteve condicionada aos princípios da indisponibilidade de direitos e da incapacidade de seus titulares. Tais princípios - que antes se aplicavam à defesa de incapazes como os menores de 16 anos, "os loucos de todo o gênero", "os surdos-mudos", "os pródigos" e "os silvícolas", nos termos do Código Civil da época - passaram a informar igualmente as leis que reconheceram direitos coletivos da sociedade. A legislação sobre interesses e direitos difusos e coletivos, iniciada com a Lei da ACP e depois expandida por novos textos legais, tão cara à experiência brasileira, seria caracterizada pela mesma ideia de hipossuficiência, mas dessa vez da própria sociedade civil. A incapacidade dessa sociedade era uma condição jurídica, não sociológica, para justificar a presença do MP na esfera cível de defesa daqueles interesses e direitos. No discurso de seus integrantes, todavia, ela é reproduzida como uma hipótese sociológica, aspecto central da ideologia do "voluntarismo político" compartilhada por promotores e procuradores de justiça.

Desse modo, não deixa de representar uma grande contradição o fato de que o mesmo processo que levou ao reconhecimento da dimensão coletiva e social de certos direitos - rompendo com o princípio individualista do ordenamento jurídico tradicional qualificou a sociedade civil como hipossuficiente ou incapaz de defender a si mesma e autorizou uma instituição do próprio Estado a agir discricionariamente e sem mandato em nome dela. Mais do que direitos positivados, a legislação nesse campo fala em "interesses", termo vago e aberto que dará ao MP a liberdade para definir a direção de suas ações em meio a conflitos coletivos. Foi assim que a instituição logrou o êxito de produzir seu "encaixe" específico, tornando-se uma espécie de representante extraordinário da sociedade alegadamente hipossuficiente. Foi esse ponto de junção da organização com o sistema institucional - para além do sistema de justiça, talvez devamos falar em sistema representativo ${ }^{10}$ - que vai Ihe permitir alcançar, na Constituinte de 1987-1988, a desvinculação em relação ao poder Executivo (ao qual estava subordinado até então), a

\footnotetext{
${ }^{9}$ Arantes (2002) examinou este e outros capítulos da trajetória de reconstrução institucional do MP, estudo no qual nos baseamos para fixar, aqui, o encaixe específico logrado pela instituição.

10 Para uma discussão da relação entre representação e o papel do Ministério Público na atuação em defesa de direitos coletivos, ver Caldeira (2017).
} 
autonomia orçamentária, financeira e administrativa e figurar em todas as leis posteriores relativas a direitos difusos e coletivos como agente tutelar da sociedade civil postulada como incapaz.

Por meio desse encaixe, o MP tornou-se o grande órgão intermediário das relações entre Estado e sociedade no Brasil, alterando significativamente os marcos da representação política e passando a ser considerado uma espécie de quarto poder. De modo independente e sem que esteja obrigado a prestar contas de sua atuação (ou de sua omissão), a presença do MP tem se destacado nas diversas dimensões da vida social e política que receberam tratamento legal na forma de interesses e de direitos difusos e coletivos: do meio ambiente ao consumidor, do patrimônio histórico à probidade administrativa, das políticas públicas à proteção de crianças, adolescentes e idosos. Poucas áreas sociais, se é que alguma, escapam à sua vigilância e interferência. Por meio de ações diretas movidas pelo procurador-geral da República (PGR) perante o Supremo Tribunal Federal (STF), o MP atua no controle da polity nos níveis federal e estadual. O PGR é líder destacado no ranking dos agentes legitimados a propor ações diretas, sendo responsável por cerca de $1 / 5$ das mais de 5 mil apresentadas desde 1988, enquanto o restante se dispersa por mais de 700 proponentes ${ }^{11}$. Por meio da Ação Civil Pública, atua no controle de policy nos mais diversos campos e, por meio da ação de improbidade e de ações penais, atua no controle dos políticos a ponto de afetar sensivelmente o jogo da politics. Pesquisas recentes sobre ações coletivas no Brasil verificaram que o MP é o seu autor mais frequente (Brasil, 2017), responsável, por exemplo, por 85,3\% dos recursos ao Superior Tribunal de Justiça em sede de ACP (Caldeira, 2017, p. 92). Ainda de acordo com a pesquisa realizada para o Conselho Nacional de Justiça $(\mathrm{CNJ})$, a legitimidade do MP para defesa de direitos coletivos é reconhecida por aproximadamente $95 \%$ dos magistrados, ao passo que a aprovação das associações civis pelos juízes cai para 55\% (Brasil, 2017), acentuando a forma paradoxal como a representação dos interesses difusos e coletivos evoluiu no Brasil.

Quanto à Defensoria Pública, embora a assistência judiciária a pessoas carentes fosse patrocinada pelo poder público de diversas formas antes de 1988, a alocação dessa função em uma instituição específica, composta por servidores concursados responsáveis por amplo rol de serviços jurídicos aos necessitados, só se deu com a atual Constituição (Rocha, 2009; Cunha, 2001; Moreira, 2016, 2017). De certo modo, é como se a primeira onda de acesso à justiça descrita por Cappeletti e Garth (1988) conhecesse novo impulso depois que a segunda alavancou uma instituição do próprio Estado à condição de defensora da sociedade, mas deixou espaço aberto para a defesa individual de pessoas necessitadas, algo que o próprio Ministério Público estava impedido de assumir.

Até 1988, cada estado brasileiro definia seu arranjo institucional de assistência judiciária, e as soluções praticadas variavam quanto ao órgão/profissão jurídica responsável pela tarefa. Esse período representou uma fase de dispersão dos modelos de

11 Ver estatísticas sobre controle concentrado no site do STF: <http://www.stf.jus.br>. Acesso em: 18 out. 2017. 
assistência judiciária pelo país. Todavia, é possível sistematizá-los em três formas principais (Moreira, 2016): 1) criação de um órgão público específico para prestar assistência judiciária, dando lugar, em alguns casos, ao surgimento das primeiras Defensorias; 2) atribuição da função a algum órgão jurídico já existente na estrutura da administração pública, normalmente a Procuradoria-Geral do Estado (PGE); ou 3) a remuneração, com recursos do orçamento público, de advogados particulares que atendiam à demanda por serviços jurídicos das camadas mais pobres da população. Essa última solução poderia ser combinada com uma das duas primeiras, como ocorria, e ainda ocorre, no estado de São Paulo.

Dentre as diferentes experiências estaduais, a do Rio de Janeiro se notabilizou pela precoce criação da Defensoria Pública em 1954, inicialmente sob o nome de "Assistência Judiciária" (AJ). Essa carreira jurídica estatal estava inicialmente vinculada ao MP fluminense, embora não fizesse parte dos quadros profissionais dos promotores/procuradores de justiça. Nas décadas seguintes, o grupo específico de defensores públicos do Estado testemunharia a trajetória do MP, de conquista de novas funções e de crescente autonomia. Esse exemplo inspirou os defensores, que com o tempo passaram a argumentar que seria necessário formar uma instituição equivalente ao MP (autônoma e com garantias profissionais) para desempenhar efetivamente os serviços de assistência jurídica, que, em muitos casos, envolviam litígios contra o próprio Estado e/ou com empresas com forte poder econômico. Durante as décadas de 1970 e 1980, a AJ do Rio de Janeiro, impulsionada pelos defensores públicos, seguiu o caminho da autonomia administrativa e funcional (Rocha, 2004, p. 34-51). Em 1987, a AJ consolida esse processo, sendo alçada ao patamar de Secretaria de Estado. Foi também nesse ano que a instituição ganhou definitivamente o nome de Defensoria Pública, "para diferenciá-la das demais

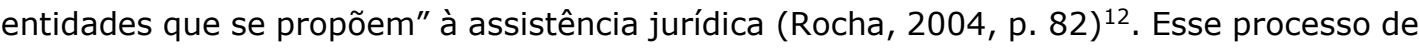
institucionalização foi conduzido, em grande medida, pela atuação política dos defensores, principalmente por meio da associação representativa da categoria (Rocha, 2004; Moreira, 2016).

No começo dos anos 1980, a institucionalização da Defensoria fluminense influenciou servidores públicos que prestavam a assistência judiciária em outros estados, os quais começaram a reivindicar um modelo semelhante ao do Rio de Janeiro (Moreira, 2016; Moraes e Silva, 1984, p. 94-99). Espelhando a evolução do MP, o projeto de nacionalização de um modelo de DP foi levado por defensores públicos, assistentes judiciários e suas diversas associações à Assembleia Nacional Constituinte (ANC) de 198788 (Neder, 2008). Todavia, outras carreiras jurídicas reagiram contra a ambição dos defensores públicos. Os debates na ANC revelam que procuradores estaduais e advogados de certos Estados se posicionaram contra o projeto de uniformização da assistência jurídica

\footnotetext{
12 "Assistência judiciária" e "assistência jurídica" são empregadas indistintamente neste artigo. Contudo, há uma diferença no uso dessas expressões. Assistência jurídica tornou-se recorrente a partir da década de 1980, substituindo a noção de assistência judiciária, considerada restritiva demais, por transmitir a ideia de que a ajuda legal se limita à defesa perante o Judiciário, sem incluir atividades de orientação sobre direitos e atuação em vias extrajudiciais. Para definição dos conceitos, ver Marcacini (1996).
} 
com base no modelo de uma DP autônoma, porque essas carreiras já desempenhavam tal função naqueles lugares. Além disso, membros do próprio Ministério Público não queriam a criação de uma nova instituição no sistema de justiça em paridade com o MP (Moreira, 2017).

O resultado desses embates sobre a assistência jurídica durante a ANC foi a redação original do artigo 134 da Constituição, que previu a Defensoria Pública como instituição essencial à administração da justiça, cujo ingresso se dá por concurso público. No entanto, a oposição de outras carreiras jurídicas surtiu efeito, de tal modo que a autonomia da DP não foi inserida na Constituição nesse momento e o artigo em questão era vago, dando margem para que alguns estados atrasassem por muitos anos a criação de suas próprias Defensorias (Moreira, 2017). Nas décadas seguintes, defensores públicos lutaram para criar a DP em todos os Estados, bem como para obter a autonomia da instituição. Novamente, para atingir tais objetivos seria preciso enfrentar os interesses de carreiras jurídicas e instituições do sistema de justiça. Para implantar a Defensoria em todo o país, foi preciso superar a resistência da PGE e/ou da Ordem dos Advogados do Brasil (OAB) nos Estados onde a assistência judiciária estava a cargo de procuradores e/ou advogados particulares. Esses locais, apesar da previsão constitucional da DP, demoraram anos, em alguns casos décadas, para instituir a Defensoria, pois a oposição corporativa das carreiras jurídicas retardou o surgimento da nova instituição. De maneira oposta, os estados que possuíam algum órgão específico de assistência judiciária antes de 1988 criaram a DP rapidamente, pois neles havia uma categoria profissional interessada no surgimento da nova instituição: os próprios servidores da assistência jurídica. Para eles, o modelo constitucional era mais vantajoso, já que trazia maior estabilidade e garantias, e a Constituição autorizava os antigos servidores da assistência judiciária a ingressarem na DP quando criada (Moreira, 2016).

Nesse processo de afirmação institucional da DP, a força normativa do argumento residia na necessidade de completar o acesso à justiça, depositando numa nova instituição a tarefa de assistência jurídica aos indivíduos necessitados. Esse foi o encaixe alcançado, não sem enfrentar muitos conflitos com outros interesses organizados, pela Defensoria Pública. A defesa jurídica dos necessitados implicará inúmeras oportunidades de atuação, que poderão se traduzir em políticas públicas levadas a cabo pela instituição, como no exemplo da assistência a presos que se desdobra em ações coletivas, em mudanças legais como a criação da audiência de custódia, e até em atuação pela reforma do sistema carcerário como um todo. Ao caminhar nessa direção, a defesa da policy afeta o jogo da politics, e a DP se constitui também em ator provocador da accountability do sistema político, seja pelo exercício da defesa de indivíduos que cobram medidas efetivas do Estado, seja pelo ajuizamento de ações coletivas contra o poder público.

A terceira instituição que integra nossa análise representa igualmente uma importante inovação institucional no cenário brasileiro contemporâneo: a Polícia Federal. Por meio de suas operações cotidianas de combate à corrupção e ao crime organizado, a 
PF tornou-se uma das instituições mais reverenciadas do país. Desde que o Índice de Confiança Social do Ibope passou a incluir a PF como uma das instituições pesquisadas em 2016, a corporação policial ocupa o terceiro lugar do ranking, abaixo apenas do Corpo de Bombeiros e das Igrejas e acima das outras 17 instituições pesquisadas, inclusive das Forças Armadas ${ }^{13}$. Trata-se de mais um exemplo de organismo estatal que encontrou seu encaixe no sistema institucional e busca por meio dele desenvolver graus cada vez mais elevados de estruturação e autonomia.

A constituição histórica da PF é relativamente recente, sendo sua origem mais remota o Departamento Federal de Segurança Pública (DFPS), criado em 1944, mas com atuação inicial restrita ao Distrito Federal. Foi apenas com o governo militar pós-64 que a PF passou a ter jurisdição nacional, graças à Lei 4.483/64, cuja data de promulgação (16/11/1964) é comemorada como data de aniversário da corporação. A Constituição de 1988 foi a primeira a mencionar explicitamente a PF, por meio do art. 144, estabelecendo também suas principais competências. Vinculada ao Poder Executivo Federal, no âmbito do Ministério da Justiça, e colocada ao lado das polícias civis e militares estaduais, e das polícias rodoviária e ferroviária federais, a PF foi definida como órgão permanente e com estruturação em carreira, dois elementos fundamentais para o seu processo de institucionalização. A Constituição também fixou suas funções gerais e específicas. De modo específico, cabe à PF combater o tráfico de drogas e o contrabando. De modo geral, cabe-lhe atuar nos crimes contra a "ordem política e social" - expressão que remonta à época da ditadura - e proteger os bens, serviços e interesses da União. Esse último aspecto é o que tem lhe permitido atuar em todo o território nacional onde o patrimônio da União está em risco ou sob denúncias de desvios e corrupção. É também função geral da PF atuar nos crimes de dimensão internacional, exercendo funções de polícia marítima, aeroportuária e de fronteiras. E o termo "federal" ganha especial sentido quando a constituição estabelece que cabe a essa polícia apurar as infrações que tenham repercussão interestadual e exijam repressão uniforme nos estados envolvidos (Arantes, 2011b).

O sopro inicial de renovação da PF veio de fora e seu encaixe no sistema institucional foi favorecido pelo movimento mais amplo de fortalecimento dos órgãos de controle da administração pública e da classe política, no combate à corrupção e à improbidade administrativa. Uma primeira brisa de reconstrução ocorreu no final do governo FHC, quando novas contratações por concurso público passaram a renovar os quadros da PF. O sopro mais forte, contudo, ocorreu sob o governo Lula, especialmente pela liderança do ministro da Justiça Marcio Thomaz Bastos, que atuou pela completa reestruturação da corporação, em termos organizacionais, de recursos humanos e de remuneração de seus quadros. Concursos para os cargos de delegado de Polícia Federal, perito criminal, agente federal, escrivão de polícia e papiloscopista foram realizados e mais

\footnotetext{
13 Para mais informação, consultar o site: <http://www.ibopeinteligencia.com/>. Acesso em: 15 out. 2017.
} 
de 5 mil pessoas foram contratadas somente nos primeiros anos do governo Lula ${ }^{14}$. Até 2004, a PF sequer dispunha de quadro administrativo próprio e naquele ano foram abertas quase 1.700 vagas para inaugurá-lo. Num curto espaço de tempo, a PF deixaria para trás a imagem de uma polícia desaparelhada e ineficiente, conquistaria confiança junto ao MPF e à Justiça Federal e passaria a atuar, na forma de Força-Tarefa, na companhia de agentes da Receita Federal, da Controladoria-Geral da União (CGU), de técnicos dos vários ministérios atacados por corrupção, bem como de funcionários de outros órgãos de fiscalização (Arantes, 2011b).

O encaixe específico da PF se deu, entretanto, no contexto das transformações do sistema de justiça, especialmente de sua parte dedicada ao combate à corrupção política. Conforme Arantes demonstrou (2011a, 2011b), a década de 1990 havia sido marcada pela inauguração de uma nova forma de controle da administração pública, introduzida pela Lei da Improbidade Administrativa. Aprovada em 1992, na esteira da crise que levaria ao impeachment do presidente Collor, essa lei deslocou o combate à corrupção da esfera penal para a esfera cível, permitindo que o MP conduzisse investigações por meio de inquéritos civis e movesse ações civis públicas de improbidade administrativa com muito mais desenvoltura do que as ações penais, que impunham uma série de dificuldades e obstáculos. Não estando sujeita aos rigores do Código Penal, a hipótese de improbidade administrativa cometida por qualquer autoridade pode ser investigada diretamente por promotores e procuradores que atuam na primeira instância da justiça, sem a necessidade de participação da Polícia e sem a supervisão do Judiciário, tal como ocorre com o inquérito policial. O foro de julgamento, portanto, é sempre o primeiro grau e mesmo autoridades constituídas não têm direito ao chamado foro privilegiado, que se limita às hipóteses criminais. Se condenado em Ação Civil Pública por improbidade administrativa, o acusado perde o mandato e tem seus direitos políticos suspensos por 8 a 10 anos, além de ser obrigado a ressarcir os cofres públicos. Apenas não é condenado à prisão. Por conta dessas vantagens, a atuação pela via da improbidade administrativa se tornou a estratégia dominante dos membros do MP nos anos 1990.

Entretanto, passadas duas décadas de experiência, um balanço das ações de improbidade indicaria o seu baixo grau de efetividade processual, isto é, poucas ações resultaram de fato em medidas efetivas contra os envolvidos em escândalos de corrupção. O que parecia uma vantagem da via cível se convertera no seu infortúnio: começar na primeira instância parecia algo animador, mas também implicava a possibilidade de inúmeros recursos a instâncias superiores e o retardamento, agravado pela morosidade da justiça, da condenação final.

Se nos anos 1990 a impunidade era associada à baixa eficiência do sistema penal, baseado na necessária, porém ineficaz, triangulação de competências entre Polícia, MP e Judiciário, os tempos recentes têm sido marcados por uma inversão desse diagnóstico,

14 No caso dos peritos, várias profissões foram incorporadas, tais como engenheiros, contadores, economistas, médicos, analistas de sistemas, odontólogos, farmacêuticos, geólogos e físicos. 
com a via cível da improbidade passando a segundo plano e cedendo lugar estratégico à via criminal de combate à corrupção, especialmente na forma das grandes operações capitaneadas pela PF. Esse deslocamento - da esfera cível à criminal - ocorreu por duas razões principais: uma organizacional, que diz respeito ao processo de reestruturação da $\mathrm{PF}$, e outra intencional, que diz respeito ao novo modus operandi daquelas três instituições centrais na atividade de persecução penal. Hoje, investigações envolvem mecanismos mais eficazes de obtenção de provas e de desmantelamento de organizações criminosas, tais como escutas telefônicas, mandados de busca e apreensão, prisões preventivas ou temporárias e, finalmente, as famosas delações premiadas.

Foi nesse contexto que o enquadramento criminal voltou a ser considerado e nele a PF encontrou o seu encaixe no sistema institucional, ao se apresentar como uma organização capaz de recuperar a eficiência e o prestígio do inquérito policial, para que a via criminal de combate à corrupção pudesse ser retomada, agora não mais sob os olhares desconfiados do Ministério Público e do Judiciário, mas como órgão capaz de levar adiante, com sucesso, as investigações. Em entrevista a Arantes, Luiz Fernando Correa, ex-diretorgeral da Polícia Federal (2007-2011), um dos principais responsáveis pelo processo de reestruturação da PF nesse período, indicou o ponto exato de junção da organização com o sistema institucional:

Nós colocamos como ponto central de todo esse modelo gerencial a questão da cadeia de custódia de prova, um termo que o meio acadêmico usa, e eu introduzi um termo um pouquinho antes, cadeia de produção e custódia de prova, porque o meio acadêmico consolidou "custódia de prova" como uma coisa do laboratório pra diante, e na minha visão o comportamento policial no lugar do crime faz parte da prova, principalmente nos delitos que a Polícia Federal apura, porque atinge criminalidade organizada, criminalidade que envolve pessoas com grande poder aquisitivo, intocáveis até então, mas com grande poder de resposta, de peso político e capacidade de resposta técnica, com grandes escritórios de advogados que vão saber combater o trabalho da polícia (...). Então o eixo central dessa ponte, no leito do abismo, é a produção e custódia de provas... e depois vem gestão, qualidade do gasto, sustentabilidade... mas essa é a razão de ser porque polícia judiciária nós somos $^{15}$ (Correa, 2012) (grifos nossos).

O encaixe da PF diz respeito, em suma, à produção e qualidade da prova, elemento central para o bom funcionamento do sistema de justiça criminal. Todo o processo de reestruturação da PF passou a se orientar por essa razão de ser, da organização interna às interações entre os seus diversos departamentos, do planejamento à execução das grandes operações, da socialização de seus membros ao empenho pelo desenvolvimento

\footnotetext{
15 Entrevista concedida em 22/12/2010, no âmbito do projeto de pesquisa "Polícia Federal e Ministério Público no combate à corrupção e ao crime organizado no Brasil (CNPq 401224/2010-4, vigência 1/8/2010 31/7/2012). Coordenação: Rogério Bastos Arantes.
} 
DEMOCRACIA, INSTITUIÇÕES DE CONTROLE E JUSTIÇA SOB A ÓTICA DO PLURALISMO ESTATAL

de uma "ciência criminal" (debatida em congressos no Brasil e no exterior), do investimento em técnicas e equipamentos a uma expertise profissional que busca combinar o combate ao crime e o respeito aos princípios do direito.

Dentre os três casos estudados aqui, o da PF ilustra de modo especial a importância teórica da noção de encaixe. Se nos casos do MP e da DP os encaixes se encontram na órbita do sistema que habitam, o caso da PF revela a decisão de uma corporação de sair da alçada do Executivo para fixar seu ponto de junção no sistema de justiça. Ela bem que poderia ter estabelecido como encaixe a estreita obediência às políticas do Executivo, tornando-se assim um braço importante do presidente eleito e legitimado pelo voto popular, e auferindo como recompensa o reconhecimento político. Mas a corporação preferiu caminhar na direção da justiça, "porque polícia judiciária nós somos", encaixandose entre o Ministério Público e o Judiciário, no ponto frágil do inquérito policial, renovandoo e emprestando-Ihe uma eficiência que não detinha.

Embora nenhuma instituição esteja imune à politização, a escolha pelo sistema de justiça como campo mais promissor à afirmação institucional de longo prazo também diminui o risco da partidarização e tenta unificar os integrantes na busca de uma autonomia própria dos corpos judiciais, e do reconhecimento pelas demais profissões jurídicas, algo bastante caro a essas corporações. Nesse sentido, cumprir com eficiência ordens judiciais expedidas a pedido de procuradores pode levar a PF ao êxito de se afirmar no longo prazo, mais do que servir aos interesses do poder Executivo ao qual está formalmente vinculada. Mas, ao desempenhar essa policy específica, afeta sensivelmente a dinâmica da politics e se vê por ela afetada, como temos visto nas inúmeras operações de combate à corrupção e ao crime organizado, especialmente a Lava Jato. Seja como for, essas operações, conduzidas pela trinca de juízes, procuradores e delegados, atestam o êxito das respectivas estratégias de afirmação institucional e do grau de cooperação entre esses atores, inédito na história do sistema de justiça brasileiro.

Em termos gerais, a evolução das três instituições aqui examinadas - o MP, a DP e a PF - pautou-se pela construção de encaixes específicos que lhes propiciaram ocupar um lugar no sistema institucional mais amplo e, a partir dos respectivos pontos de junção, lutar por graus mais elevados de independência e de fortalecimento organizacional.

Os dois outros fatores que compõem o nosso modelo de análise dizem respeito ao grau de coesão interna de cada uma dessas instituições e à capacidade de resistir aos ataques externos. Se os respectivos encaixes nos ensinam sobre os êxitos alcançados por elas, o nível de coesão interna e a capacidade de resistir/enfrentar adversidades externas são elementos úteis de comparação sobre as diferenças que marcam as três trajetórias.

No que diz respeito à questão da coesão da corporação, não pretendemos fazer uma análise organizacional exaustiva, que envolveria diversos aspectos internos, da forma de ingresso às formas de ascensão e promoção, controle e uso dos recursos disponíveis, capacidades institucionais instaladas, processos de gestão e de tomada de decisão, prerrogativas individuais e mecanismos de coordenação do trabalho coletivo, ideologia e 
valores que caracterizam o esprit de corps, hierarquia e distribuição de poder no interior dessas organizações. Nos limites deste artigo, apontamos para os fatores mais conhecidos acerca da dinâmica interna dessas instituições e que, por ora, nos permitem afirmar que MP, DP e PF se distinguem, nessa ordem, do maior ao menor grau de coesão interna, comparativamente falando.

Poder-se-ia objetar que, se os graus de coesão interna são distintos (como veremos a seguir) por que esse fator comporia um modelo de análise destinado a explicar trajetórias de afirmação institucional que convergem para o pluralismo estatal? A resposta é que quem não alcançou ainda elevado grau de coesão está em busca dessa medida, pois enxerga na experiência dos bem-sucedidos nessa dimensão a condição para o êxito de seus projetos de afirmação institucional.

Não só por ser a mais antiga das três e por contar com um lugar institucional claro há mais tempo, o MP goza de uma coesão interna bastante forte e um esprit de corps tão bem definido que raramente vemos a instituição mergulhando em conflitos internos significativos. Do ponto de vista organizacional, o MP combina um baixo grau de hierarquia entre a cúpula da organização e seus diversos membros (Kerche, 2009), mas compartilha de modo bastante extensivo o que Arantes (2002) identificou, com base em surveys e entrevistas qualitativas, como ideologia do voluntarismo político. Tal ideologia foi decisiva no processo endógeno de reconstrução histórica do MP e tem se mantido como combustível importante da atuação de seus membros, pelo menos daqueles que se identificam com a função de representante extraordinário da sociedade e defensor de seus interesses difusos e coletivos. A ideologia do voluntarismo político está baseada:

[n]uma avaliação crítica e pessimista da sociedade civil (tanto de suas carências quanto de sua incapacidade de mobilização) e também dos Poderes de Estado (que se encontram divorciados da sociedade e incapazes de efetivar seus direitos fundamentais). Desse binômio negativo emerge o terceiro elemento da matriz ideológica do voluntarismo político: cabe ao Ministério Público tutelar os direitos dessa sociedade civil fraca, dirigindo suas ações prioritariamente contra o Estado inoperante e as instituições políticas muitas vezes corrompidas por interesses particularistas (Arantes, 2002).

A suposta fragilidade da sociedade civil e a incapacidade das instituições políticas de representar adequadamente essa mesma sociedade conformam um desses lugarescomuns do imaginário político brasileiro, o qual suscitou historicamente aventuras autoritárias, antipolíticas e antidemocráticas no país. Como vimos, a ideia de hipossuficiência caracteriza o fundamento da legislação sobre direitos difusos e coletivos, antes que a própria sociedade civil. Nesse sentido, é uma construção jurídica, mais do que sociológica, que reproduz o poder da própria instituição que é colocada no papel de representante extraordinário (porque não autorizado diretamente, nem passível de destituição) dessa mesma sociedade. As centenas de inquéritos civis e de ações civis públicas inauguradas cotidianamente pelo MP, ao mesmo tempo que visam defender 
direitos coletivos, reforçam aquela assimetria de poder e retroalimentam a ideologia do voluntarismo político.

Quando apontamos a elevada coesão interna do MP não estamos afirmando que seus membros marchem unidos no dia a dia de suas funções. A coesão se dá em torno da busca permanente por garantias, prerrogativas e privilégios. Uma delas, talvez a mais valorizada, é a "independência funcional" que assegura ampla margem de ação individual e autônoma a seus membros, a ponto de dificultar ou mesmo impedir quaisquer tentativas de planificação das atividades da organização (Sampaio, 2017). Em resumo, são unidos no princípio que Ihes garante independência para marcharem sozinhos.

Da Defensoria Pública não se pode dizer, pela forma como se deu a sua criação nos estados e na União, que disponha de uma coesão interna similar à do Ministério Público. Embora a Constituição de 1988 tenha estabelecido um modelo único de assistência jurídica, a forma como cada unidade federativa criou a sua Defensoria variou significativamente, como vimos. Em muitos casos, a iniciativa de forjar a nova instituição se deu por aliança de diferentes grupos que passaram a disputar seu controle no momento seguinte. Há divergências sérias acerca da ancoragem da DP: enquanto alguns permanecem presos à velha prática de buscar a proteção do Executivo, quase sempre por razões corporativas, outros buscam apoio na sociedade, junto a movimentos sociais e organizações civis de defesa de direitos.

A Associação Nacional dos Defensores Públicos (Anadep) realizou quatro surveys com integrantes da DP nos estados e na União nos anos de 2004, 2006, 2009 e $2015^{16}$. No primeiro deles, verificou-se que, apesar da uniformidade trazida pela legislação, o quadro organizacional nos estados ainda era marcado por grande heterogeneidade e, em muitos deles, sequer a capacidade de autogestão e a autonomia em relação ao Executivo estavam asseguradas. Mesmo nos mais recentes levantamentos, apesar de a grande maioria dos defensores professar a causa da defesa dos necessitados como uma de suas principais razões para ingressar na Defensoria, ainda é elevado o número daqueles que gostariam de exercer outros cargos, especialmente os de magistrados e de membros do Ministério Público, e que se declaram em preparação para prestar concursos públicos para essas carreiras. Tais surveys também cobriram questões polêmicas, e não foram pequenos os percentuais daqueles que concordam com a diminuição da maioridade penal, com o aumento de penas e o porte de armas para defensores públicos.

A principal divisão interna da DP, a despeito das variações decorrentes da formação da instituição em cada estado, está associada ao conflito entre dois projetos institucionais que permeiam a categoria profissional dos defensores (Moreira, no prelo). Por um lado, conforme vimos acima, por décadas os defensores se espelharam na trajetória de êxito do MP, buscando consolidar uma Defensoria Pública autônoma e em grande medida insulada das influências da sociedade, capaz de agir com independência para representar os

16 Disponíveis em: <https://www.anadep.org.br/wtk/pagina/diagnosticos>. Acesso em: 10 out. 2017. 
interesses e direitos da população carente. Esse projeto de institucionalização foi encampado pelos defensores na Constituinte e durante toda a década de 1990, sendo decisivo para as pretensões da categoria durante a elaboração da Lei Complementar no 80/94, que dispõe sobre a organização da Defensoria da União e traça normas gerais para as Defensorias estaduais. Por outro lado, na virada do século um novo projeto institucional despontou durante o processo de criação da Defensoria Pública do Estado de São Paulo (DPesp). Nesse estado, desde a década de 1980 a assistência judiciária era incumbência de um departamento da PGE, a Procuradoria de Assistência Judiciária (PAJ), que dividia o grande volume de serviços com advogados privados credenciados pela OAB estadual. No processo de criação da Dpesp, liderado por um grupo de procuradores da PAJ em parceria com movimentos sociais (Moreira, 2016; Zaffalon L. Cardoso, 2010), surgiu uma nova concepção de Defensoria, aberta à participação e ao controle social, por meio de canais institucionais permeáveis às demandas de grupos sociais que atuam em nome de setores das populações vulneráveis que formam o público-alvo da Defensoria. Tal aliança se mostrou estratégica para superar os vetos impostos pelo modelo de assistência judiciária centrada na PGE e compartilhada com a OAB até então existente.

Conduzida por um grupo de defensores públicos com acesso à Secretaria de Reforma do Judiciário do Ministério da Justiça desde a aprovação da Emenda Constitucional no 45/2004, a proposta de consolidar o novo perfil institucional de Defensoria em todo o país ganhou força política, e logo uma reforma da Lei Complementar (LC) da instituição passou a ser reivindicada por esse grupo de defensores. Em 2009 foi aprovada Lei Complementar no 132 que inovou em três eixos principais: 1) fixar a defesa e a promoção de direitos humanos como a missão da Defensoria; 2) priorizar novos mecanismos para tutelar os interesses jurídicos dos grupos sociais atendidos pela Defensoria, sobretudo a Ação Civil Pública, as soluções extrajudiciais de litígios e a educação em direitos; 3) construir uma instituição mais aberta e transparente à sociedade, por meio da criação da ouvidoria externa da Defensoria Pública.

Apesar das inovações no plano legislativo, boa parte dos defensores públicos foi resistente às mudanças que pretendiam abrir a Defensoria para que atores societais pudessem apresentar sugestões, reivindicações e críticas à instituição. Conforme relatou em entrevista o ex-presidente da Anadep, Fernando Calmon, a negociação do projeto de Lei Complementar com os colegas de profissão foi a etapa mais difícil no processo de aprovação da lei:

(...) ela [proposta de lei] foi totalmente negociada com a classe. Ela levou seis anos de tramitação interna, no legislativo foi a parte mais fácil. Incrível. A gente precisava acertar com todas as lideranças da Defensoria nos Estados, (...) foi difícil, porque a gente estava, por exemplo, mudando os eixos da instituição, e a gente tinha que convencer os colegas. Nós temos dificuldade, por exemplo, com a questão da ouvidoria (Zaffalon L. Cardoso, 2016). 
Essa objeção de parte expressiva dos defensores à proposta de abertura da instituição persiste. Trata-se de um choque entre perfis institucionais distintos: o projeto de tornar a estrutura administrativa permeável e responsiva aos atores societais esbarra em outro, geralmente atrelado a interesses corporativos de segmentos da carreira. Esses segmentos entendem que a proposta de abrir a instituição para a participação social é algo incompatível com certos interesses da categoria profissional, frequentemente associados a vencimentos e prerrogativas funcionais, e com o rumo que pretendem trilhar para a Defensoria, seguindo experiência de instituições já tradicionais do sistema de justiça, a saber, o MP e o próprio Judiciário. Nesse modelo tradicional, carreiras jurídicas pretendem incorporar funções de representação de direitos e de controle sobre atividades de interesse público, mas fecham-se para a sociedade, evitam a interação com atores societais e não se sujeitam a medidas de accountability. Defensores vinculados a essa concepção de instituição jurídica tendem a perceber como uma ameaça, ou como um projeto irrealizável, a proposta de transformar a Defensoria em um espaço de construção coletiva de políticas públicas de acesso à justiça. Até mesmo na Dpesp, que foi criada com mecanismos participativos e atingiu o nível mais expressivo de interação com atores da sociedade civil, é forte a resistência no interior da carreira às iniciativas para implementar a participação e o controle de atores sociais nas diretrizes da instituição (Zaffalon L. Cardoso, 2016; Moreira, no prelo). Em 2017, por exemplo, o Conselho Superior da DPESP alterou a regra de escolha do ouvidor-geral externo da instituição, encerrando a indicação por entidades da sociedade civil.

Em resumo, embora a DP tenha alcançado um elevado grau de institucionalização, nos Estados e na União, as divergências internas sobre o modelo de defensoria persistem e por vezes comprometem seu grau de coesão, inclusive na luta pela afirmação institucional.

Das três instituições aqui examinadas, a PF é a menos coesa porque sua organização interna se baseia em carreiras independentes e que disputam entre si, de modo às vezes extremamente conflitivo, os níveis de remuneração, o acesso a cargos estratégicos e de chefia, e o comando geral da instituição. A principal divisão ocorre entre os Delegados de Polícia - também chamados de "bacharéis", porque necessariamente formados em Direito - e os Agentes - policiais federais de nível superior, mas não necessariamente formados em Direito. Do ingresso à promoção, da hierarquia ao preenchimento de cargos, Delegados e Agentes perfazem carreiras independentes de ponta a ponta. Todavia, enquanto os primeiros ocupam a quase totalidade dos cargos de direção e dispõem de maior remuneração, os segundos recebem salários mais baixos e ocupam postos subservientes aos Delegados. As diversas carreiras no interior da PF formam associações, sindicatos e federações, que lutam pelas respectivas categorias e muitas vezes entre $\mathrm{si}^{17}$, como veremos mais adiante no exemplo da PEC no 37.

17 Os delegados estão reunidos nacionalmente na Associação Nacional dos Delegados de Polícia Federal (<www.adpf.org.br/>) e no Sindicato dos Delegados de Polícia Federal (<http://sindepol.org.br>), com 
A baixa coesão interna tem atrasado seu processo de afirmação institucional. Das três instituições, a PF é a única que ainda não dispõe de Lei Orgânica pós-Constituição de 1988 , por conta dos conflitos inconciliáveis que marcam as diferentes carreiras internas. O Projeto de Lei 6.493, que trata do tema e visa substituir a Lei Orgânica de 1965 (Lei 4.878/65), tramita na Câmara desde 2009. Várias audiências foram convocadas com diretores da instituição e lideranças sindicais e associativas, e vários debates parlamentares foram travados no âmbito da Comissão Especial destinada a proferir parecer sobre o projeto ${ }^{18}$. A falta de acordo sobre as prerrogativas das diferentes carreiras e particularmente a reivindicação dos agentes federais no sentido de assumir cargos de comando, quando não a possibilidade de assumir as próprias vagas abertas por delegados, têm impedido a aprovação da nova lei. Diante do impasse, a Federação Nacional dos Policiais Federais passou a apoiar a Proposta de Emenda à Constituição - PEC 361/2013, que mantém as atuais competências da PF, mas unificaria as carreiras atuais numa só, fazendo desaparecer as diferenças de status, poder e remuneração existentes entre elas ${ }^{19}$.

No que diz respeito aos conflitos e disputas de fronteira, terceiro fator que compõe nosso modelo de análise, pode-se começar pela Constituinte de 1987-1988, quando o lobby do MP atuou de maneira organizada e alcançou seu maior objetivo, o de tornar-se independente em relação ao poder Executivo, beneficiando-se do ambiente favorável à incorporação de uma instituição com ampla capacidade de fiscalização e controle dos poderes políticos (Kerche, 2009). De lá para cá, sempre que a instituição se viu ameaçada por tentativas de retrocesso, como a da "lei da mordaça" nos anos 1990 (que constrangia a forma de atuação de seus membros) ou mais recentemente da PEC no 37 (que retiraria da instituição o poder de investigação), o MP soube reagir de modo unificado, conquistando o apoio da mídia e da opinião pública, interrompendo assim aquelas iniciativas. Mudanças como a introdução de recurso, com efeito suspensivo, contra a instauração do inquérito civil ou mesmo algum tipo de supervisão judicial do instrumento têm sido discutidas, assim como a extensão do foro privilegiado das ações penais para as ações civis de improbidade, mas nenhuma delas até hoje foi aprovada.

Ao contrário de derrotas, o MP só conheceu avanços, sejam corporativos, sejam institucionais. Na esteira da Constituição, leis orgânicas estaduais e de âmbito nacional consolidaram diversas garantias e prerrogativas, bem como novas leis de direitos difusos e coletivos Ihe reservaram papel de destaque. Alguns avanços foram inclusive informais e

unidades também organizadas nos estados. Os policiais estão reunidos nacionalmente na Federação Nacional dos Policiais Federais (<www.fenapef.org.br>), com unidades sindicais também nos estados, e um importante histórico de greves e movimentos de reivindicação da categoria. Os peritos se reúnem sob a Associação Nacional dos Peritos Criminas Federais (<www.apcf.org/>), os escrivães sob a Associação Nacional dos Escrivães da Polícia Federal (<anepf.blogspot.com.br>), e os papiloscopistas sob a Associação Brasileira dos Papiloscopistas Policiais Federais (Abrapol).

18 Informações disponíveis em: <http://www2.camara.leg.br/atividade-legislativa/comissoes/comissoestemporarias/especiais/55a-legislatura/pl-6493-09-lei-organica-da-policia-federal-1>. Acesso em: 29 out. 2017.

19 Apelidada de "PEC do FBI", supostamente por assemelhar a PF à famosa polícia federal norte-americana, a PEC 361/2013 permitiria que os atuais integrantes das diversas carreiras optassem pela carreira única cuja promoção daí por diante dar-se-ia por critérios de mérito e antiguidade - preservados todos os demais direitos, ou então permanecessem nos cargos atuais, formando assim um quadro em extinção. 
ao arrepio da Constituição. Exemplo importante se deu com o método de escolha do procurador-geral da República, chefe do Ministério Público Federal e da União. Segundo a Constituição federal, enquanto as chefias dos MPs estaduais são escolhidas pelos governadores e aprovadas pelas Assembleias Legislativas a partir de lista tríplice eleita pelos próprios integrantes da instituição (art. $128 \S 3^{\circ}$ ), o procurador-geral da República é escolhido livremente pelo Presidente, dentre quaisquer membros da instituição, e aprovado pelo Senado (art. $128 \S 1^{\circ}$ ). Em 2000, no âmbito da tramitação da Reforma do Judiciário, os procuradores federais tentaram introduzir a lista tríplice para escolha do PGR, mas a proposta só contou com 246 dos 308 votos necessários (Arantes, 2002, p. 279). A partir de 2001, à revelia da Constituição e da vontade manifesta do Congresso, a Associação Nacional dos Procuradores da República (ANPR) passou a realizar consulta junto à classe e a levar seu resultado ao presidente. FHC foi o primeiro a receber essa lista tríplice informal, mas a ignorou. Na sequência, Lula passou a respeitar o resultado das escolhas da ANPR, indicando sempre o primeiro lugar na lista, no que foi acompanhado por sua sucessora, Dilma Rousseff. Somente na última indicação, feita por Temer em 2017, a prática foi parcialmente alterada, com a indicação da segunda colocada, mas que recebeu assim mesmo amplo respaldo da instituição.

Outro avanço alcançado pelo MP diz respeito à formação de grupos de atuação especial e das chamadas forças-tarefas. Como contrapartida da independência funcional de seus membros, conquistada como equiparação da independência dos juízes, o MP deveria respeitar o princípio do promotor natural, tal como a magistratura respeita o princípio do juiz natural. Nesses casos, as expressões indicam que as causas são distribuídas aleatoriamente a juízes e promotores, e estes não têm a prerrogativa de escolher aquelas. Todavia, o MP encontrou uma forma de contornar essa limitação, formando grupos autônomos para atuação em causas pré-selecionadas, a partir de designações da chefia da instituição. Esse tipo de discricionariedade para definir linhas de atuação, como explica Kerche (2009), é próprio dos modelos de MP sujeitos a alguma forma de responsabilização política, direta ou indireta, mas não deveria ocorrer em modelos baseados no princípio da independência como o brasileiro.

No bojo da Reforma do Judiciário de 2004, o MP também ganhou um órgão de controle para chamar de seu, o Conselho Nacional do Ministério Público (CNMP). Embora não contemos com estudos sistemáticos de suas atividades, é possível afirmar que, tal como o Conselho Nacional de Justiça, o CNMP se converteu em órgão de administração da própria corporação, da elaboração de políticas e metas para seus membros, antes que um órgão de efetivo controle externo ${ }^{20}$.

20 O caso da tentativa de nomeação de Wellington Lima e Silva, integrante do MP da Bahia, como ministro da Justiça por Dilma Rousseff em 2016 ilustra este ponto. Questionada perante o STF por ofender a regra constitucional que proíbe o acúmulo de cargos (salvo um de magistério), a nomeação não se consumou, mas no decorrer do processo se descobriu que o próprio CNMP havia editado resolução em 2011 autorizando a prática. No julgamento do caso envolvendo o procurador nomeado por Dilma, o ministro do Supremo Gilmar 
Em resumo, as ações do MP no controle da polity, da policy e da politics alcançaram seu auge nos tempos recentes, e por isso têm despertado reações do Congresso, do poder Executivo e, de modo frequente, do Supremo Tribunal Federal. Todavia, na sua disputa por fronteiras, o MP praticamente não conheceu derrota significativa nesses 30 anos de Constituição e segue vitorioso na defesa de suas prerrogativas.

No front externo, a luta da Defensoria Pública por afirmação institucional não se resumiu à Constituinte, inclusive porque a Constituição de 1988 não fixou todas as garantias almejadas pelo lobby da instituição, principalmente por conta da objeção de outras carreiras jurídicas, conforme vimos acima. No pós-88, uma das principais fontes de oposição ao projeto de desenvolvimento da DP partiu do próprio Ministério Público, que não via com bons olhos a criação de uma nova instituição quase à sua imagem e semelhança. O choque entre a ambição dos defensores e a oposição do MP se deu, por exemplo, na aprovação da Lei Complementar nº 80/1994, que definiu as normas gerais da Defensoria Pública, conforme previa a Constituição. Por meio da LC n 80/94, os defensores públicos pretendiam forjar uma estrutura administrativa e alcançar prerrogativas semelhantes às do Ministério Público. A lei previa, por exemplo, os princípios institucionais da unicidade, indivisibilidade e independência, os mesmos que a Constituição estabelece para o MP e que os defensores tentaram sem sucesso inserir no artigo constitucional relativo à Defensoria. Todavia, dispositivos importantes da LC 80/1994 foram vetados pelo presidente da República, em grande medida a pedido do então procurador-geral da República, Aristides Junqueira (Moreira, 2016). Os vetos foram a: 1) previsões que concediam autonomia administrativa e financeira à Defensoria Pública; 2) dispositivos que conferiam novas funções ou instrumentos jurídicos para a atuação dos defensores públicos, como a legitimidade para ajuizar Ação Civil Pública $(A C P)$; 3) regras sobre vencimentos que equiparavam a remuneração dos defensores aos salários de membros da magistratura e do MP, bem como concediam auxílio-moradia e outras gratificações; e 4) normas funcionais que atribuíam prerrogativas dos membros do MP, como porte de arma e foro privilegiado, aos defensores públicos ${ }^{21}$.

A autonomia financeira e administrativa, um dos principais temas reivindicados pelos defensores desde a Constituinte, só seria constitucionalmente estabelecida uma década depois de promulgada a Lei Complementar, com a aprovação da Emenda Constitucional (EC) no 45/2004. Durante a longa tramitação da Reforma do Judiciário no Congresso, os defensores lograram elevado grau de coesão e, especialmente por meio da atuação do então deputado federal e defensor fluminense Iédio Rosa, conseguiram inserir o princípio da autonomia no projeto de emenda. Com o apoio do governo petista a partir

Mendes afirmou que a Resolução no 72 era "um verdadeiro estupro constitucional". O STF declarou a norma inconstitucional e o Conselho foi obrigado a revogá-la.

${ }^{21}$ As razões de veto citaram o parecer do PGR, afirmando que certas funções, como o ajuizamento de ACP, são inerentes ao MP e que os defensores não devem ter "prerrogativas ou direitos diversas daquelas atribuídas aos advogados". Razões de veto apresentadas na Mensagem no 27/1994 da Presidência da República. Disponível em:

<http://www2.camara.leg.br/legin/fed/leicom/1994/leicomplementar-80-12-janeiro-1994-363035-veto-

19294-pl.html>. Acesso em: 6 maio 2016. 
DEMOCRACIA, INSTITUIÇÕES DE CONTROLE E JUSTIÇA SOB A ÓTICA DO PLURALISMO ESTATAL

de 2003, os defensores conseguiram vincular suas reivindicações ao projeto de ampliação do acesso à justiça (Moreira, 2016, p. 104-107).

Seguramente o principal e mais arrastado embate envolvendo defensores e membros do MP ocorreu em torno da legitimidade da Defensoria para ajuizar Ações Civis Públicas. Enquanto vários integrantes do Ministério Público consideram que a defesa de direitos difusos e coletivos é, ao menos quando exercida por um órgão estatal, uma atribuição constitucional exclusiva do MP, vários defensores vêm utilizando a ACP desde o início dos anos 1990 como instrumento jurídico destinado à defesa de pessoas carentes nos casos em que a demanda envolvia direitos coletivos. Mesmo sem disposição legal que autorizasse claramente a Defensoria a fazer uso da ACP, a instituição forçou a fronteira com o MP, não sem amargar muitos resultados negativos por extinção do processo sem julgamento de mérito, por simples ilegitimidade de sua condição de autora da demanda coletiva. Em 2007, a Lei 7.347/85 da ACP foi modificada para incluir a DP no rol dos legitimados a fazer uso da Ação Civil Pública. Ato contínuo, a Conamp, Associação Nacional dos Membros do Ministério Público, ingressou com ação direta de inconstitucionalidade perante o STF (ADI 3943) para derrubar essa mudança legal. O impasse só foi resolvido anos depois, quando em 2015 o STF finalmente declarou que a Defensoria poderia fazer uso da ACP no cumprimento de suas funções institucionais.

Em resumo, a pretensão de afirmação institucional da DP esbarrou ao longo do tempo na resistência de outros agrupamentos jurídicos, tais como o Ministério Público, a $O A B$ e outras carreiras de Estado responsáveis pela assistência jurídica aos necessitados. O longo e intrincado processo de desenvolvimento institucional da Defensoria foi resultado, em grande medida, de embates entre grupos autointeressados e corporativistas (Moreira, 2016). Se hoje a instituição está instalada em todos os estados da federação, isto não deve obscurecer as diferentes trajetórias de cada criação e a forte oposição que a DP enfrenta por parte de outros atores jurídicos.

Quanto à Polícia Federal, vimos que sua ascensão esteve associada a uma recuperação do prestígio do inquérito policial e das atividades de investigação levadas a cabo pela corporação. Foi animado por esse contexto que o deputado federal Lourival Mendes, do PT do B do Maranhão, delegado de Polícia e liderança da categoria em seu estado, avaliou que era chegada a hora de dar o troco no MP, propondo a PEC no 37 . A proposta visava acrescentar um novo parágrafo ao artigo 144 da Constituição: "A apuração das infrações penais de que tratam os $\S \S 1^{\circ}$ e $4^{\circ}$ deste artigo incumbem (sic) privativamente às polícias federal e civis dos Estados e do Distrito Federal, respectivamente". Em sua breve justificativa, o deputado maranhense acusava a existência de "procedimentos informais de investigação" que estariam sendo conduzidos indevidamente por diversos órgãos e defendia o inquérito policial, uma exclusividade da Polícia, como "verdadeira garantia ao direito fundamental do investigado no âmbito do devido processo legal", por supostamente estar submetido a regras claras e à supervisão 
do Poder Judiciário. Seu alvo eram claramente as investigações conduzidas pelo Ministério Público.

Nos anos 1990, o MP havia defendido o fim do inquérito policial e sua substituição por novos procedimentos sob a presidência de promotores e procuradores. Com o declínio da estratégia centrada no combate à corrupção como improbidade administrativa e a recuperação da efetividade da investigação policial, o ex-delegado do Maranhão considerou que seria possível afugentar de uma vez por todas o MP da seara de atuação policial. Entretanto, a Comissão Especial que tratou da PEC no 37 constatou que, hoje, um grande número de órgãos e instituições realizam investigação no Brasil, de tal modo que a eventual aprovação da emenda não atingiria apenas as atividades do Ministério Público, mas também as da Receita Federal, das Agências Reguladoras, do Banco Central, do Conselho Administrativo de Defesa Econômica (Cade), da CGU, da Previdência Social, dentre outros, que investigam crimes sob sua jurisdição, sem falar nas Comissões Parlamentares de Inquérito e nos Tribunais de Contas, que também seriam afetados pela mudança (Arantes, 2013).

O debate no âmbito da Comissão acabou evoluindo para um substitutivo bem mais complexo, que regulava a atividade de investigação contemplando os diferentes órgãos. Quando as ruas exigiram a derrota da "PEC da impunidade" (como ficou conhecido o projeto, graças à forte campanha de mídia articulada pelo próprio MP), a comissão retirou o substitutivo e ofereceu em sacrifício no altar das grandes manifestações a proposta original do deputado maranhense que sequer seria aprovada num teste de língua portuguesa ${ }^{22}$. O resultado da votação pela Câmara dos Deputados foi de acachapantes 430 votos contrários e apenas 9 a favor da versão original da PEC no 37.

Embora o exemplo demonstre os conflitos entre MP e PF em torno do monopólio da investigação, esse caso também ilustra os conflitos internos à própria Polícia Federal, como adiantamos no exame do seu baixo grau de coesão interna. Enquanto os Delegados se mostraram favoráveis à aprovação da PEC no 37, pois eles presidem os inquéritos policiais na órbita federal, os policiais federais se organizaram para lutar contra a proposta, justamente para não emprestar mais poder aos delegados. Associações e sindicatos da categoria participaram de manifestações públicas e deram declarações contrárias à PEC. "Nossa posição é de repúdio à emenda e de parceria com o Ministério Público", afirmou o então presidente do Sindicato dos Policiais Federais (Sindipol) no Distrito Federal, Flávio Werneck. Sob os argumentos de que "quem investiga é o agente, o escrivão, o papiloscopista" e que "os delegados só pegam o relatório, copiam e colam, e encaminham ao Ministério Público", o então presidente da Federação Nacional dos Policiais Federais (Fenapef), Jones Borges Leal, chegou a afirmar que a função do delegado era cada vez mais "dispensável" e que, "se nós hoje tirarmos esse cargo, nada mudaria na segurança

22 O texto com a regulação das atividades de investigação dos diferentes órgãos tramita na forma do PL $5776 / 2013$. 
pública. Os policiais investigariam da mesma forma e encaminhariam ao MP, talvez com mais rapidez e agilidade"23.

Apesar das divisões internas e da oposição frequente do MP, a PF não deixou de galgar degraus cada vez mais elevados de autonomia e de afirmação institucional e segue empenhada na ampliação de suas fronteiras. Em 2014, quando as investigações da operação Lava Jato batiam às portas do Planalto, a Presidente editou a Medida Provisória (MP) no 657/2014, depois convertida em lei pelo mesmo Congresso acuado pelas denúncias de corrupção, estabelecendo critérios para a escolha do cargo de diretor geral da Polícia Federal dentre integrantes de classe especial da carreira dos delegados, além de outras medidas de reforço institucional da corporação. Tramita no Congresso a PEC no 412/2009, que estabelece, na linha do mimetismo com o Judiciário, o Ministério Público e a Defensoria Pública, autonomia funcional e administrativa e iniciativa de proposta orçamentária da PF. Há campanhas também pela adoção da lista tríplice com mandato para diretor geral e pela criação de um Conselho Nacional de Polícia Judiciária, a exemplo do CNJ e do CNMP. Em 2018, a corporação foi transferida do Ministério da Justiça para o então criado Ministério da Segurança Pública. Tal mudança não altera sua condição de polícia judiciária, mas, ao deslocar o foco da policy - do combate à corrupção para a segurança pública -, representará um importante teste no processo de afirmação institucional da PF.

Uma última consideração sobre os conflitos de fronteiras entre esses órgãos diz respeito ao papel de árbitro que vem sendo exercido pelo STF. Durante todo o período, o Tribunal tem sido provocado sobre inúmeras questões que afetam o desempenho dessas instituições. Foram várias as vezes que os poderes das diversas instituições aqui analisadas estiveram sub judice no Tribunal, especialmente quando envolviam e envolvem ações de combate à corrupção. O Tribunal e seu órgão auxiliar, o CNJ, já decidiram sobre uso de algemas, escutas telefônicas, quebras de sigilos e até chegaram a proibir que processos judiciais fossem identificados pelos nomes midiáticos dados às operações. Mais especificamente sobre fronteiras de autoridade, o STF foi instado a se manifestar sobre a questão do poder de investigação do MP e na última vez em que se pronunciou, no julgamento do Recurso Extraordinário 593727 (com Repercussão Geral) decidiu que o MP detém competência para promover, por autoridade própria, investigações de natureza penal, ao mesmo tempo que fixou certos parâmetros ${ }^{24}$. Foi também o STF que, não sem protelar por vários anos, decidiu que a DP podia fazer uso da Ação Civil Pública no desempenho de suas tarefas institucionais, conforme vimos acima, no julgamento da ADI 3943 patrocinada pela Conamp, associação nacional dos membros do MP. Moreira (2016) levantou 34 ações de controle concentrado no STF envolvendo direitos e prerrogativas da

23 Informação em: <http://politica.estadao.com.br/noticias/geral,agentes-da-policia-federal-apoiam-mpcontra-pec-37,1046433>. Por Andrea Jubé Vianna, Agência Estado. 24/6/2013. Acesso em: 5 nov. 2017. 24 Ver tema 184, na relação de Teses de Repercussão Geral, no site do STF: <http://www.stf.jus.br>. Acesso em: 10 nov. 2017. 
DP25. Segundo o autor, especialmente a partir de 2004, o Tribunal passou a tomar decisões favoráveis à institucionalização das defensorias nos estados, assegurando sua autonomia administrativa e financeira ${ }^{26}$. Outra fronteira importante que o STF foi chamado a definir envolveu PF e MP no que diz respeito à possibilidade de conduzir delações premiadas. A Lei das Organizações Criminosas autoriza explicitamente a Polícia a fechar acordos de colaboração, mas o procurador-geral da República ingressou com Ação Direta de Inconstitucionalidade contra a lei (ADI 5508), contestando essa prerrogativa e clamando para que as delações só tenham validade se aprovadas pelo MPF. O STF decidiu por maioria de $8 \times 3$ a favor da Polícia, em julgamento iniciado em 13/12/2017 e somente concluído em 20/6/2018. Em resumo, esses e outros $\operatorname{casos}^{27}$ revelam três aspectos cruciais da relação do STF com o fenômeno do pluralismo estatal: 1) não é o legislador mas a Corte quem está definindo as fronteiras de atuação dos diferentes órgãos; 2) o Tribunal nunca decide rapidamente e pode levar anos até se posicionar a favor de uns e outros; 3) quando finalmente decide, o faz para manter as funções de quem está sendo atacado e contra as pretensões de quem quer monopolizar todo o espaço de atuação (o MP pode investigar, contra a pretensão da Polícia; a PF pode realizar acordos de colaboração premiada, contra a pretensão do MP; e a DP pode usar Ação Civil Pública, contra a pretensão do MP).

\section{Considerações finais: uma releitura do sistema de justiça e accountability brasileiro}

Em meio à controvérsia estabelecida sobre o papel que instituições do campo da justiça têm desempenhado na democracia brasileira, este artigo fornece novos elementos teóricos, um modelo de análise e um primeiro exercício de comparação da trajetória de três importantes instituições - Ministério Público, Defensoria Pública e Polícia Federal -, inspirados no conceito de pluralismo estatal. Conforme observamos, estamos diante da formação de grupos de interesse no interior do Estado, que possuem suas próprias pautas de afirmação institucional e agem politicamente para tornar suas demandas exitosas. Esse

\footnotetext{
25 Tais como equiparação com outras carreiras, concurso público como forma de ingresso, autonomia e funções, convênio com a OAB vs. modelo constitucional da DP, dentre outros.

26 Mesmo assim os conflitos da DP com outros atores interessados na prestação da assistência jurídica aos necessitados não cessam e continuam sendo levados ao STF, como a ADI 5644, movida pela Associação Nacional de Defensores Públicos (Anadep), questionando a Lei Complementar 1.297/2017, do estado de São Paulo, que vinculou parte do orçamento da Defensoria Pública estadual, correspondente a $40 \%$ do Fundo de Assistência Judiciária (FAJ), para o pagamento de advogados privados, algo que contrariaria decisão anterior do próprio STF, na ADI 4163.

27 Estão na pauta do STF: conflito entre MP, CGU e TCU em torno da autoridade para firmar acordos de leniência (ADI 5466); proibição do TCU de decretar indisponibilidade de bens (MS 35506); ações de inconstitucionalidade movidas pela Confederação Brasileira de Trabalhadores Policiais Civis (Cobrapol) (ADI 5073), pelo PGR (ADI 5043) e pela Associação Nacional das Operadoras de Celulares (Acel) (ADI 5059) contra a Lei $12.830 / 2013$, que, segundo os autores, atribui poderes excessivos aos delegados de polícia, induzindo à interpretação de que o poder de investigação seria atribuição exclusiva destes. O STF terá que julgar ainda a ADI 5649, da Associação Nacional dos Delegados de Polícia Federal (ADPF), contra dispositivo do Regulamento Administrativo do Senado Federal (Rasf) que permite à Polícia Legislativa do Senado instaurar e conduzir inquéritos policiais. Na ADI 5296, o STF julga a constitucionalidade da autonomia conferida à Defensoria Pública da União, em pedido feito pela presidência após ser instigada pela AGU. Se procedente, tal ADI pode ter reflexo sobre a autonomia das DPs estaduais.
} 
DEMOCRACIA, INSTITUIÇÕES DE CONTROLE E JUSTIÇA SOB A ÓTICA DO PLURALISMO ESTATAL

fenômeno é capturado pelo conceito de pluralismo estatal e permite compreender mudanças importantes no sistema de justiça brasileiro, além de lançar luz sobre a atuação estratégica de atores estatais na cena política. Em diversas situações, não se trata simplesmente das "instituições funcionando" ou da partidarização seletiva da justiça, para empregar jargões do atual debate político brasileiro, mas sim da ambição de carreiras públicas e da ação estratégica de seus membros com relação a fins.

A análise comparada de MP, DP e PF feita neste artigo nos permite qualificar melhor a relação que essas instituições mantiveram e mantêm com a Constituição de 1988. Do MP se pode dizer que logrou construir seu encaixe antes de 1988, e a Constituição veio coroar seu processo de afirmação institucional concedendo-Ihe independência e autonomia externas. O pós-88 foi completado por leis infraconstitucionais e o desafio da instituição foi resistir a tentativas de retrocesso em suas funções e poderes. Da DP se pode dizer que tem na Constituição de 1988 a uniformização nacional de seu encaixe no sistema de justiça, obrigando estados com maior ou menor experiência prévia de assistência jurídica aos necessitados a adotarem o mesmo figurino. Entretanto, no pós-88 foram necessárias várias emendas constitucionais para completar o trabalho de 1988, conquistar a almejada autonomia e reforçar os incentivos aos estados para aderirem ao marco da Constituição, não sem decisões importantes do STF a pavimentarem esse caminho. Da PF se pode dizer que tem na Constituição de 1988 apenas definições gerais que, apesar de importantes, não foram portadoras de seu encaixe no sistema institucional mais amplo. Este se desenvolveu a posteriori, graças principalmente à estratégia dos próprios membros da corporação de se tornarem relevantes para o sistema de justiça por meio da qualidade da prova. Em termos de independência e autonomia, a PF é, dentre os três, a mais atrasada, e suas clivagens internas, associadas à vinculação constitucional com o Executivo, têm dificultado os passos nessa direção.

Assim, embora a Constituição de 1988 tenha sido uma etapa importante no processo de reconstrução institucional dos órgãos de justiça, ela não representa um plano geral e articulado de desenvolvimento dessas instituições em conjunto, que operam mais por razões de autointeresse e corporativas do que de modo externamente coordenado pela ordem constitucional ou por terceiros. É por essa razão que preferimos falar em pluralização do Estado como resultado geral desse modo de construção institucional, em vez de um sistema global previamente concebido de acesso à justiça e de accountability, de um lado, ou de uma mera instrumentalização política para ações partidariamente seletivas, de outro.

Do ponto de vista da teoria democrática, assumir que instituições do próprio Estado possam buscar graus tão elevados de autonomia e de afirmação é seguramente algo problemático. Considerar que, nesse processo, reconfiguram a representação política ao assumirem funções para atuar em nome de interesses sociais, sem que isso signifique um fortalecimento da própria sociedade, talvez seja algo mais grave do que a hipótese hoje ventilada de politização (em sentido partidário) da justiça. Mais do que ou tão preocupante 
quanto a politização partidária é a "política para si", que faz da ideia de representação da sociedade um mero passaporte para a afirmação de seus próprios interesses. Entre o governo dos homens e o governo das leis, tais instituições preconizam o governo dos homens de leis. Essa forma de governo não se assemelha ao Estado de Direito, nem torna a democracia necessariamente mais responsiva, embora torne o Estado mais plural, do ponto de vista dos órgãos e corporações que habitam seu interior e competem por recursos, funções, prerrogativas e vencimentos. Em vez de fortalecer a defesa de interesses sociais por meio da ampliação dos canais e atores de representação (Vianna et al., 1999), o processo de expansão das instituições judiciais e de controle rege-se em função de seus próprios integrantes e da promoção de seus projetos e aspirações.

Desse modo, na perspectiva do pluralismo estatal, o termo pluralismo, em regra empregado na teoria política liberal com valor positivo para descrever certo equilíbrio na distribuição de poderes e recursos nas democracias (Dahl, 1991, 1997), perde aqui essa conotação normativa, pois revela o resultado agregado dos movimentos autointeressados das instituições de justiça e de controle em busca de afirmação institucional e do afastamento de qualquer forma de accountability sobre suas atividades. Nesse sentido, permite-nos ir além das análises que, centradas nas teorias institucionalistas, perdem de vista o próprio Estado e como este, de instância supostamente universal, converte-se numa pluralidade de órgãos capazes de agir em função de seus próprios interesses. Por outro lado, e de modo complementar, os integrantes de tais órgãos podem ser vistos como atores em busca de rendimentos que só no âmbito do Estado é possível alcançar, sobretudo depois que conquistam autonomia orçamentária e administrativa para alocar, a seu bel interesse, com boa margem de discricionariedade e sem qualquer forma de accountability, os recursos financeiros junto aos seus.

Não obstante, a abordagem do pluralismo estatal também é capaz de mostrar como a contenção dos avanços e abusos de tais atores pode vir da própria interação entre eles, já que a ambição de certas carreiras estatais tende a esbarrar nos interesses de outras. Afinal, parodiando Madison (1993) nos "artigos federalistas" (1787-1788), talvez a única garantia contra a concentração de poder seja propiciar àqueles que administram os diversos órgãos de controle os meios necessários e os motivos pessoais para resistirem aos ataques uns dos outros. As garantias de defesa devem ser proporcionais às formas de ataque, o interesse das carreiras jurídicas deve estar associado aos direitos constitucionais dos cargos e a ambição de uns deve jogar contra as ambições de outros. Assim tem sido, em grande medida, a dinâmica do pluralismo estatal brasileiro.

A presente abordagem também nos permitiu observar como as dimensões da policy e da politics se confundem na atuação desses organismos estatais. MP, DP e PF são responsáveis pela condução de políticas públicas (lato sensu), mas como estas interferem de um modo ou de outro no jogo da politics, é natural que na interação entre si e sobretudo com as instituições políticas definam suas estratégias quanto à policy de olho nos desdobramentos no âmbito da politics. E vice-versa. 
Tratando-se de carreiras jurídicas, as metas do MP, da DP e da PF para alcançar a afirmação institucional são bem conhecidas, sendo cotidianamente almejadas por eles: 1 ) autonomia financeira, administrativa e funcional; 2) independência assegurada pela forma de ingresso (concurso público), e pelas formas de promoção na carreira e de escolha da chefia que sejam as menos suscetíveis possíveis à interferência externa; 3) conquista de garantias individuais de exercício do cargo, tais como vitaliciedade, inamovibilidade e irredutibilidade de vencimentos, capazes de assegurar independência funcional a seus membros; 4) vedações ao exercício de cargos fora da carreira; e 5) volume de recursos legais e materiais. Nosso plano de pesquisa futura pretende comparar a trajetória das três instituições em relação a esses cinco indicadores principais, e explorar como outras instituições, tais como CGU e AGU, traçam estratégias para atingir objetivos semelhantes. Embora a receita de sucesso pareça clara, atingi-lo é algo que depende do êxito em reunir os três fatores mencionados neste artigo: encaixe, coesão interna e capacidade de mover fronteiras ou de entrincheirar-se na defesa de suas próprias. Como vimos, ainda que os respectivos encaixes tenham se mostrado precisos e promissores como alavancas da afirmação institucional do MP, da DP e da PF, os níveis de coesão e a capacidade de ataque/defesa foram e têm sido distintos ao longo das respectivas trajetórias, o que provavelmente explica os diferentes graus de êxito alcançado na conquista das cinco metas mencionadas acima.

\section{Referências bibliográficas}

Abers, R.; Serafim, L. S.; TATAgiba, L. "Repertórios de interação Estado-sociedade em um Estado heterogêneo: a experiência na era Lula". Dados, Rio de Janeiro, vol. 57, n² 2, p. 325-357, 2015.

ABERS, R.; TATAGIBA, L. Institutional activism: mobilizing for women's health from inside the bureaucracy. In: RossI, F.; VoN BüLLow, M. (eds.). Social movement dynamics: new perspective on theory and research from Latin America. Farnham: Ashgate, p. 73-101, 2015.

ABERS, R.; Von BülLow, M. "Movimentos sociais na teoria e na prática: como estudar o ativismo através da fronteira entre Estado e sociedade?". Sociologias, vol. 13, n²8, p. 52-84, 2011.

ALMEIDA, D. R. "Representação como processo: a relação Estado/sociedade na teoria política contemporânea". Revista de Sociologia e Política, vol. 22, p. 175-199, 2014.

AlmeidA, F. "A nobreza togada: as elites jurídicas e a política da justiça no Brasil". Tese de Doutorado, Universidade de São Paulo, São Paulo, 2010.

. "Os juristas e a política no Brasil: permanências e reposicionamentos". Lua Nova, São Paulo, nº 97, p. 213-250, 2016.

Alonso, A. "As teorias dos movimentos sociais: um balanço do debate". Lua Nova, São Paulo, no 76, p. 49-86, 2009.

ALSTON, L., et al. Brazil in transition. Beliefs, leadership, and institutional change. Princeton: Princeton University Press, 2016.

ARANTeS, R. B. Ministério Público e política no Brasil. São Paulo: Idesp; Sumaré: Educ, 2002. 
The federal police and the Ministério Público. In: POWER, T.; TAYLOR, M. (orgs.). Corruption and democracy in Brazil. Notre Dame: University of Notre Dame Press, p. 184-217, $2011 a$.

Polícia Federal e construção institucional. In: Avritzer, L.; FilgueirAS, F. (orgs.). Corrupção e sistema político no Brasil. Rio de Janeiro: Civilização Brasileira, 2011 b.

. "PEC 37: o que as ruas não perceberam". Le Monde Diplomatique, vol. 76, 2013.

. "Rendición de cuentas y pluralismo estatal en Brasil: Ministerio Público y Policía Federal".

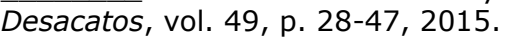

ARANTES, R.; MoreirA, T. Defensoria Pública e acesso à justiça no novo CPC. In: Didier JR., F.; SousA, J. A. (orgs.). Defensoria Pública - Coleção repercussões do novo CPC. Salvador: Editora Juspodivm, 2015.

ARANTES, R. B.; REIS, B. P. W. Instituições políticas e controles democráticos: o paradoxal exercício simultâneo do poder e de sua contenção. In: MARTINS, C. B.; LeSSA, R. (orgs.). Horizontes das ciências sociais no Brasil: ciência política. São Paulo: Anpocs, p. 241-270, 2010.

ARANTES, R. B, et al. Controles democráticos sobre a administração pública no Brasil: Legislativo, Tribunais de Contas, Judiciário e Ministério Público. In: LouReIRO, M. R.; ABRUCIO, F. L.; PACHECO, R. S. V. M. (orgs.). Burocracia e política no Brasil: desafios para a ordem democrática no século XXI. Rio de Janeiro: Editora FGV, p. 109-147, 2010.

Avritzer, L. Impasses da democracia no Brasil. Rio de Janeiro: Civilização Brasileira, 2016.

AVRITZer, L.; MARONA, M. "A tensão entre soberania e instituições de controle na democracia brasileira. Dados, Rio de Janeiro, vol. 60, n² 2, p. 359-393, 2017.

Bonelli, M. G. Profissionalismo e política no mundo do direito. São Carlos: Edufscar; Sumaré: Fapesp, 2002.

Bonelli, M. G.; OliveirA, F. L. "A política das profissões jurídicas: autonomia em relação ao mercado, ao Estado e ao cliente". Revista de Ciências Sociais, Fortaleza, vol. 34, n 1, p. 99-114, 2003.

BRASIL. Conselho Nacional de Justiça. Ações coletivas no Brasil: temas, atores e desafios da tutela coletiva. Mendes, C. H.; Oliveira, V. E.; Arantes, R. B. Seminário Justiça Pesquisa, 2017. Sumário Executivo disponível em:

<http://www.cnj.jus.br/files/conteudo/arquivo/2018/01/ee3f22cd4cddac54ce99ced5beeeaa91.pdf>. Acesso em: 20 abr. 2018.

CALDEIRA, V. S. "Representação de interesses coletivos pela via judicial: ações civis públicas julgadas pelo Superior Tribunal de Justiça (de 2006 a 2015)". Tese de Doutorado em Sociologia, Universidade Federal do Paraná, Curitiba, 2017.

CAPpelletti, M. "Formações sociais e interesses coletivos diante da justiça civil". Revista de Processo, São Paulo, n 5, 1977.

Cappelletti, M.; Garth, B. Acesso à justiça. Porto Alegre: Fabris, 1988.

CoRrEA, L. F. Entrevistador: R. B. Arantes. Brasília. 1 arquivo .mp3 (147 min.), 2012.

Couto, C. G.; ARANTES, R. B. "Constituição, governo e democracia no Brasil". Revista Brasileira de Ciências Sociais, São Paulo, vol. 21, n 61, 2006.

CunhA, L. G. Acesso à justiça e assistência jurídica em São Paulo. In: SAdEK, M. T. (org.). Acesso à justiça. São Paulo: Fundação Konrad Adenaeur, 2001.

DAHL, R. Los dilemas del pluralismo democrático: autonomia versus control. México: Alianza Editorial, 1991. 
DEMOCRACIA, INSTITUIÇÕES DE CONTROLE E JUSTIÇA SOB A ÓTICA DO PLURALISMO ESTATAL

Poliarquia: participação e oposição. São Paulo: Edusp, 1997.

DoWBoR, M. W. "A arte da institucionalização: estratégias de mobilização dos sanitaristas (19742006)". Tese de Doutorado em Ciência Política, Universidade de São Paulo, São Paulo, 2012.

FONSECA, T. N. "O TCU na Assembleia Nacional Constituinte 1987/1988: atuação e resultados". In: IV Seminário Discente da Pós-Graduação em Ciência Política da USP, São Paulo (SP), 2014.

GeDDES, B. "Building 'State' autonomy in Brazil, 1930-1964". Comparative Politics, vol. 22, n², p. 217-235, 1990.

Gurza Lavalle, A. "Crítica ao modelo da nova sociedade civil". Lua Nova, São Paulo, vol. 47, p. 121$135,1999$.

Gurza Lavalle, A.; HoutZager, P.; CAStello, G. "Democracia, pluralização da representação e sociedade civil". Lua Nova, São Paulo, n 67, p. 49-103, 2006.

Gurza Lavalle, A.; SzWako, J. "Sociedade civil, Estado e autonomia: argumentos, contraargumentos e avanços no debate". Opinião Pública, Campinas, vol. 21, n 1, p. 157-187, 2015.

GuRZA LAVAlLE, A., et al. "Movimentos sociais, institucionalização e domínios de agência". Texto para Discussão no 019/2017 ISSN 2177-9015. Centro de Estudos da Metrópole, São Paulo, 2017.

HALL, P.; TAYLOR, R. "As três versões do neoinstitucionalismo". Lua Nova, São Paulo, no 58, p. $193-$ 223, 2003.

KERCHE, F. Virtude e limites: autonomia e atribuições do Ministério Público no Brasil. São Paulo: Edusp, 2009.

LIPSKY, M. Street-level bureaucracy: dilemmas of the individual in public service. New York: Russell Sage Foundation, 1980.

LOTTA, G. S. "Implementação de políticas públicas: o impacto dos fatores relacionais e organizacionais sobre a atuação dos burocratas de nível de rua no Programa Saúde da Família". Tese de Doutorado em Ciência Política, Universidade de São Paulo, São Paulo, 2010.

MADEIRA, L. Acesso à justiça e as reformas judiciais: o caso da Defensoria Pública. In: SANTOS, J. T.; MAdeirA, L. M. (orgs.). Segurança cidadã. Porto Alegre: Tomo Editorial, p. 41-61, 2014.

MADISON, J. Os artigos federalistas (1787-1788). Rio de Janeiro: Nova Fronteira, 1993.

MAInWARING, S.; WeLnA, C. Democratic accountability in Latin America. Oxford: Oxford University Press, 2003.

MANN, M. "The autonomous power of the state: its origins, mechanisms and results". European Journal of Sociology, vol. 25, no 2, p. 185-213, 1984.

MARCACINI, A. T. R. Assistência jurídica, assistência judiciária e justiça gratuita. Rio de Janeiro: Forense, 1996.

MARQUES, E. "Notas críticas à literatura sobre Estado, políticas estatais e atores políticos". BIB Boletim Bibliográfico de Ciências Sociais, São Paulo, nº 43, p. 67-102, 1997.

Moraes, H. P.; Silva, J. F. T. Assistência judiciária: sua gênese, sua história e a função protetiva do Estado. $2^{a}$ ed. Rio de Janeiro: Liber Juris, 1984.

MoReIRA, T. M. Q. "A criação da Defensoria Pública nos estados: conflitos corporativos e institucionais no processo de uniformização do acesso à justiça". Dissertação de Mestrado em Ciência Política, Universidade de São Paulo, São Paulo, 2016. 
ROGÉRIO B. ARANTES; THIAGO M. Q. MOREIRA

"A constitucionalização da Defensoria Pública: disputas por espaço no sistema de justiça". Opinião Pública, Campinas, vol. 23, no 3, p. 647-81, 2017.

. Defensoria Pública e judicialização de políticas públicas: expectativas e desenvolvimento. In: OliveirA, V. E. (org.). Judicialização de políticas públicas no Brasil (no prelo).

Neder, S. P. Defensoria Pública, criação da Constituição de 1988. In: Ensaios sobre impactos da Constituição Federal de 1988 na sociedade brasileira. Brasília, Câmara dos Deputados, Edições Câmara, Série Coleções Especiais - Obras comemorativas, no 2, p. 221-233, 2008.

NUNES, E. A gramática política do Brasil: clientelismo e insulamento burocrático. $4^{a}$ ed. Rio de Janeiro: Jorge Zahar Editora, 2010.

OfFE, C. Capitalismo desorganizado. São Paulo: Brasiliense, 1989.

Oliveira, V. E.; Couto, C. G. "Politização da justiça: quem controla os controladores?". In: 400 Encontro Anual da Anpocs, Caxambu (MG), 2016.

Olivieri, C. A lógica política do controle interno - o monitoramento das políticas públicas no presidencialismo brasileiro. São Paulo: Annablume, 2010.

PIERSON, P.; SKOCPOL, T. Historical institutionalism in contemporary political science. In: KATZNELSON, I.; Milner, H. (eds.). Political science: state of the discipline. New York: W. W. Norton, p. 693-721, 2002.

RochA, A. L. A exclusão legal da população carente. Brasília: Thesaurus, 2009.

Rocha, J. L. Uma história da Defensoria Pública do Estado do Rio de Janeiro e da Associação dos Defensores Públicos do Estado do Rio de Janeiro - Adperj. Rio de Janeiro: Lumen Juris, 2004.

SADEK, M. T. (org.). Uma introdução ao estudo da justiça. São Paulo: Editora Sumeré; Fundação Ford; Fundação Mellon, 1995.

. (org.). O Ministério Público e a justiça no Brasil. São Paulo: Sumaré, 1997.

SAmpaio, M. "O Ministério Público do estado de São Paulo e o seu plano geral de atuação". Dissertação de Mestrado em Administração Pública e Governo, Fundação Getúlio Vargas, São Paulo, 2017.

SCHMITTER, P. "The consolidation of democracy and representation social". American Behavioral Scientist, vol. 35, p. 422-449, 1992.

SiKKINK, K. "Las capacidades y la autonomía del Estado en Brasil y la Argentina: un enfoque neoinstitucionalista". Desarrollo Económico, vol. 32, n 128, 1993.

Silva, M.; OliveirA, G. "A face oculta(da) dos movimentos sociais: trânsito institucional e intersecção Estado-Movimento. Uma análise do movimento de economia solidária no Rio Grande do Sul". Sociologias, Porto Alegre, vol. 13, p. 86-124, 2011.

SKOCPOL, T. Bringing the state back in: strategies of analysis in current research. In: EvANS, P.; RUESSCHMEYER, D.; SKOCPOL, T. (orgs.). Bringing the state back in. Cambridge: Cambridge University Press, 1985.

Protecting soldiers and mothers: the political origins of social policy in the United States. Cambridge: The Belknap Press of Harvard University Press, 1992.

Thelen, K.; Steinmo, S. Historical institutionalism in comparative politics. In: Steinmo, S.; THELEN, K.; Longstreth, F. (eds.). Structuring politics: historical institutionalism. New York: Cambridge University Press, 1992.

TRUMAN, D. The governmental process: political interests and public opinion. New York: Knopf, 1951. ViannA, L. W., et al. Corpo e alma da magistratura brasileira. Rio de Janeiro: Revan, 1997. 
DEMOCRACIA, INSTITUIÇÕES DE CONTROLE E JUSTIÇA SOB A ÓTICA DO PLURALISMO ESTATAL

. A judicialização da política e das relações sociais no Brasil. Rio de Janeiro: Revan, 1999.

ZAfFalon L. CARDoso, L. Uma fenda na justiça - a Defensoria Pública e a construção de inovações democráticas. São Paulo: Editora Hucitec, 2010.

Zaffalon L. CARdoso, L. Entrevistador: T. M. Q. Moreira. São Paulo. 1 arquivo .mp3 (63 min.), 2016.

" "Uma espiral elitista de afirmação corporativa: blindagens e criminalizações a partir do imbricamento das disputas do sistema de justiça paulista com as disputas da política convencional". Tese de Doutorado em Administração Pública e Governo, Escola de Administração de Empresas de São Paulo da Fundação Getúlio Vargas, São Paulo, 2017.

\begin{abstract}
Democracy, institutions of control, and justice from the perspective of state pluralism

Brazil has experienced an outstanding expansion of accountability and legal institutions. However, the performance of these public agencies has been raising doubts about the effects they exert on democracy. This article comparatively analyzes the development of three legal institutions-the Public Prosecutor's Office, Federal Police, and Public Defender's Office-adopting the state pluralism theoretical approach that highlights that groups of public servants must act in their own interest in order to obtain prerogatives, functions, and autonomy. The outcome, not without frequent conflicts between these actors, is a pluralization within the State, before the proliferation of agencies that mirror their own ambitions. This approach helps to understand the current Brazilian context, plagued by the controversial interference of these institutions in the political and democratic dynamic.
\end{abstract}

Keywords: state pluralism; political activism; control institutions; institutions of justice; democracy

\title{
Resumen
}

Democracia, instituciones de control y justicia bajo la óptica del pluralismo estatal

Brasil ha experimentado una extraordinaria expansión de sus órganos de control y de promoción del acceso a la Justicia. Sin embargo, las acciones de estos órganos suscitan dudas a respeto de los efectos que ejercen en el funcionamiento de la democracia. Este artículo analiza, comparativamente, el desarrollo de tres instituciones de la Justicia - Ministerio Público, Policía Federal y Defensoría Pública - valiéndose del enfoque teórico del pluralismo estatal, que enfatiza que agentes públicos actúan en función de sus propios intereses de afirmación institucional, lanzándose en la esfera pública y en arenas políticas en busca de prerrogativas, funciones y autonomía. El resultado, no sin frecuentes embates entre estos actores, es la pluralización en el interior del Estado, con la proliferación de órganos que reflejan sus propias ambiciones. Este enfoque ayuda a comprender el actual escenario de Brasil, marcado por la controvertida interferencia de instituciones de control en la dinámica política y democrática.

Palabras clave: pluralismo estatal; activismo político; instituciones de control; instituciones de justicia; democracia

\section{Résumé}

Démocratie, institutions de contrôle et de justice dans la perspective du pluralisme d'Etat

Le Brésil a connu une extraordinaire expansion des organes de contrôle et de la promotion de l'accès à la justice. Cependant, le travail de ces organes soulève des doutes quant à leur effet sur le fonctionnement de la démocratie. Cet article analyse, comparativement, le développement de trois institutions dans le domaine de la Justice - le Ministère public, la Police fédérale et la Défense publique - sous l'approche théorique du pluralisme étatique, soulignant que les agents publics poursuivent leurs propres intérêts d'affirmation institutionnelle, dans la sphère publique et dans les arènes politiques, en quête de prérogatives, de fonctions et d'autonomie. Le résultat, non sans conflits fréquents entre ces acteurs, est la pluralisation au sein de l'État, avec la prolifération d'organes qui reflètent leurs propres ambitions. Cette approche contribue à comprendre le scénario actuel du Brésil, 
marqué par l'interférence controversée des institutions de contrôle dans la dynamique politique et démocratique.

Mots-clés: pluralisme d'État; activisme politique; institutions de contrôle; institutions de justice; la démocratie

Artigo submetido à publicação em 26 de junho de 2018. Aprovado para publicação em 25 de março de 2019.

Opinião Pública adota a licença Creative Commons CC-BY.

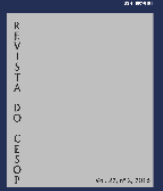

